\title{
Targeting the proper amyloid-beta neuronal toxins: a path forward for Alzheimer's disease immunotherapeutics
}

\author{
William F Goure*, Grant A Krafft, Jasna Jerecic and Franz Hefti
}

\begin{abstract}
Levels of amyloid-beta monomer and deposited amyloid-beta in the Alzheimer's disease brain are orders of magnitude greater than soluble amyloid-beta oligomer levels. Monomeric amyloid-beta has no known direct toxicity. Insoluble fibrillar amyloid-beta has been proposed to be an in vivo mechanism for removal of soluble amyloid-beta and exhibits relatively low toxicity. In contrast, soluble amyloid-beta oligomers are widely reported to be the most toxic amyloid-beta form, both causing acute synaptotoxicity and inducing neurodegenerative processes. None of the amyloid-beta immunotherapies currently in clinical development selectively target soluble amyloid-beta oligomers, and their lack of efficacy is not unexpected considering their selectivity for monomeric or fibrillar amyloid-beta (or both) rather than soluble amyloid-beta oligomers. Because they exhibit acute, memory-compromising synaptic toxicity and induce chronic neurodegenerative toxicity and because they exist at very low in vivo levels in the Alzheimer's disease brain, soluble amyloid-beta oligomers constitute an optimal immunotherapeutic target that should be pursued more aggressively.
\end{abstract}

\section{Introduction}

Alzheimer's disease (AD) is the most common form of dementia, accounting for $60 \%$ to $80 \%$ of all dementias [1,2]. Worldwide, the prevalence of dementia was more than 35 million in 2010, and projections exceed 65 million by 2030 and 115 million by 2050 [1]. Significantly, no drugs that prevent or slow the progression of $\mathrm{AD}$ are currently approved. The development of effective AD therapeutics is clearly a tremendous medical challenge and should be one of society's top medical priorities.

\footnotetext{
* Correspondence: wgoure@acumenpharm.com

Acumen Pharmaceuticals, Inc., 4453 North First Street, \#360, Livermore, CA 94551, USA
}

Despite the great need and significant societal and financial incentives, many pharmaceutical companies and investors have reduced investments in the search for new AD drugs, citing recent clinical failures of several highprofile experimental $\mathrm{AD}$ therapeutics and the high risks and costs of such development endeavors. The recent clinical failures also have intensified scrutiny of the 'amyloid cascade hypothesis', which spawned many of the recent experimental $A D$ drugs targeting the amyloid-beta $(A \beta)$ peptide. Nevertheless, the causal linkage between $A \beta$ and AD remains strong and is supported by hundreds of studies over the past two decades [3-10]. (This is a representative sample of published reviews, and apologies are given to the authors of many excellent reviews that are not cited.)

Essentially all $A \beta$ therapeutic approaches so far have targeted reducing the levels of $A \beta$ monomer or $A \beta$ deposits (or both) in the brain. However, today, the causal role of $A \beta$ in $A D$ is widely considered to involve soluble $A \beta$ oligomers, and therapeutic strategies that selectively target soluble $A \beta$ oligomers offer the potential to deliver rapid symptomatic benefit and long-term disease modification. This review describes the role of soluble $A \beta$ oligomers within the amyloid hypothesis and discusses implications for current $A \beta$ immunotherapies and new immunotherapies directed selectively toward soluble $A \beta$ oligomers.

\section{The amyloid cascade hypothesis}

The first suggestion of an 'amyloid hypothesis' to explain the pathology of $\mathrm{AD}$ was that of Wong and colleagues [11], who postulated that $A \beta$-derived cerebrovascular amyloid caused seepage of $A \beta$ and other substances from plasma into the brain, leading to the formation of $\mathrm{A} \beta$ plaques and possibly neurodegeneration. This was revised into the more well-known amyloid cascade hypothesis that proposed that deposition of $A \beta$ as neuritic plaques caused $\mathrm{AD}$ and led to neurofibrillary tangles, cell 
loss, vascular damage, and dementia [12]. The amyloid hypothesis linking $A \beta$ to $A D$ catalyzed much of $A D$ and $A \beta$ research over the past two decades, and key studies during that period led to important revisions of the hypothesis that highlighted the central role of soluble $A \beta$ oligomers in synaptic dysfunction and loss [4,13-19].

The current understanding of the $A \beta$ cascade is derived primarily from in vitro studies, the vast majority of which were conducted by using $A \beta$ concentrations orders of magnitude greater than those found in vivo. The assembly of $A \beta$ peptides to form soluble oligomers, protofibrils, and fibrils is well documented to be affected by the isoform of the starting peptide, how the peptide is treated prior to assembly, the nature of the buffer, $\mathrm{pH}$, peptide concentration, assembly temperature and time, agitation, and presence of other peptides or biological materials [20-24]. Moreover, preparations of soluble $A \beta$ species have been shown to change with time or upon dilution in different buffers, particularly in cell culture media [19]. Thus, caution must be taken in extrapolating the results and conclusions of in vitro studies to in vivo reality. Although precise mechanistic details remain to be elucidated, a multitude of studies by numerous researchers support the conclusion that monomeric $A \beta$ peptides assemble to form soluble $A \beta$ oligomers, which further aggregate to form fibrillar $A \beta[17,25]$.

Three distinct pools of $A \beta$ species exist: $A \beta$ monomers, soluble $A \beta$ oligomers, and insoluble fibrillar $A \beta$. Each of these pools encompasses an array of individual species. Thus, monomeric $A \beta$ peptides encompass various isoforms, including $A \beta(1-40), A \beta(1-42)$, and $A \beta(1-43)$, as well as numerous $\mathrm{N}$-terminal truncated isoforms. (For example, see the introductory paragraphs of Tekirian and colleagues [26].) Insoluble fibrillar $A \beta$ aggregates are also known to be heterogeneous in structure and composed of various $A \beta$ isoforms, both full-length as well as $\mathrm{N}$-terminal and C-terminal truncated isoforms. (For example, see the introductory paragraphs of Roher and colleagues [27] and Thal and colleagues [28].)

Soluble A $\beta$ oligomers are also heterogeneous and perhaps more ambiguous because of the different terminologies used by different researchers to describe them. (For an excellent review of soluble $A \beta$ oligomers, see Benilova and colleagues [9].) Thus, soluble $A \beta$ oligomer species reported by various researchers have been termed sodium dodecyl sulfate (SDS)-stable $\mathrm{A} \beta$ oligomers [29,30], low-n-oligomers [31-33], dimers [33-35], trimers [33,36-38], tetramers [37], paranuclei [38,39], dodecamers and $A \beta * 56[37,40,41]$, amyloid-derived diffusible ligands (ADDLs) [42-44], A $\beta$ oligomers [45], prefibrillar oligomers [46], A $\beta$ globulomers [40,47-49], spherical oligomers [50], amylospheroids [51,52], protofibrils $[20,53,54]$, and annular protofibrils [55,56]. Most of these terminologies refer to a mixture of metastable, soluble $A \beta$ oligomer species in equilibrium rather than a discrete, stable species. In many cases, there is similarity in the species comprising the different preparations. In this review, we will use the terminology soluble $A \beta$ oligomers to describe $A \beta$ species composed of more than one $A \beta$ peptide that remain in solution following centrifugation. $A \beta$ fibrils or fibrillar $A \beta$ will be used as a general description of insoluble $A \beta$ plaques and vascular amyloid. (The term $A \beta$ plaques rather than amyloid plaques will be used to more precisely describe amyloid plaques comprising primarily $A \beta$ peptides versus those comprising primarily non- $A \beta$ peptides.)

It has been established that the levels of $A \beta$ monomer and deposited fibrillar $A \beta$ in the $A D$ brain are orders of magnitude greater than soluble $\mathrm{A} \beta$ oligomer levels [57-65]. However, more than three decades of intense investigation has not provided a precise understanding of the extent of interconversion among the various $A \beta$ species.

$\mathrm{A} \beta$ dimers have been demonstrated to form at physiologically relevant concentrations of $\mathrm{A} \beta$ monomer in vivo $[66,67]$. Numerous in vitro studies have shown that soluble $A \beta$ oligomers and protofibrils form under similar conditions and that both species can proceed to form larger fibrillar species [20,43,53,68-74]. More recent studies provide further support for the addition of soluble $A \beta$ oligomers to protofibrillar and fibrillar assemblies and also provide data indicating that oligomerization can occur via a secondary nucleation mechanism caused by fibrillar $\mathrm{A} \beta$ $[73,74]$, possibly suggesting a mechanistic linkage between fibrillar $A \beta$ and soluble $A \beta$ oligomers. However, the precise mechanism of in vivo fibril formation has not been fully established.

$A \beta$ plaques are now generally considered to be a relatively benign species $[19,72,75]$; however, whether $A \beta$ plaques are a sink or a source for toxic soluble $A \beta$ oligomers is a subject of debate. Several studies with $\gamma$-secretase inhibitors [76-79] and two studies in transgenic mice that overexpress mutant amyloid precursor protein (APP) via a doxycycline-regulated promoter $[80,81]$ show that subchronic or chronic suppression of $A \beta$ production arrested $\mathrm{A} \beta$ plaque formation but did not result in observable clearance of existing plaques. In a related study [82], $A \beta(1-42)$ immunization of $\operatorname{Tg} 2576$ mice prior to significant $A \beta$ deposition, at an age with modest deposition or at an age with significant deposition, showed that immunization prevented additional $\mathrm{A} \beta$ deposition but did not result in significant clearance of pre-existing $A \beta$. These studies indicate that mature, dense-core $A \beta$ plaques are not in significant equilibrium with soluble $A \beta$ pools. Studies in transgenic mouse models of $A D$ reporting decreased soluble $A \beta$ oligomer levels and reduced cognitive deficits with increasing $A \beta$ plaque levels also provide support for the concept that $A \beta$ plaques may be a sink for soluble $A \beta$ species $[83,84]$. 
However, in an elegant study in APP transgenic mice using a novel microdialysis technique, the half-life of lowmolecular-weight $A \beta$ species in hippocampal interstitial fluid following inhibition of $A \beta$ production by a potent secretase inhibitor was doubled in 12- to 15-month-old mice with $A \beta$ deposits compared with 3-month-old mice without $A \beta$ deposits [85]. On the basis of these results, it was suggested that insoluble $A \beta$ was in equilibrium with soluble $A \beta$ in the interstitial fluid. In a related study using similar techniques, the temporal changes of low-molecular-weight $A \beta$ species in interstitial fluid and A $\beta$ levels in Tris-buffered saline (TBS), SDS, and formic acid extracts of brain tissues of 3-, 12-, and 24-month-old APP transgenic mice were reported [86]. A significant age-dependent decrease in low-molecular-weight $A \beta$ in interstitial fluid and significant increases in $A \beta$ species in SDS and formic acid extracts of brain tissues were found. Although $A \beta$ increased approximately seven-fold from baseline in the TBS extract of brain tissues, the level of $A \beta$ in TBS extracts was less than $2 \%$ of the total $\mathrm{A} \beta$ in SDS and formic acid extracts. These results indicated an agedependent sequestration of $A \beta$ as non-diffusible cell matrix and membrane-bound $A \beta$ and deposited $A \beta$ plaques. Acute $\gamma$-secretase inhibition of $A \beta$ production in plaque-free and plaque-rich mice suggested that $A \beta(1-42)$ in the interstitial fluid of plaque-rich mice was derived primarily from $A \beta(1-42)$ sequestered in brain parenchyma rather than from new biosynthesis. However, it was not possible to determine whether cell matrix and membranebound $A \beta$ or $A \beta$ plaques or both forms of $A \beta$ were the source of $A \beta(1-42)$ in the interstitial fluid of aged mice.

In a more recent study of the temporal changes of $A \beta$ species in the interstitial fluid and brain tissues of APP transgenic mice, Takeda and colleagues [87], using a 1,000-kDa-molecular-weight cutoff microdialysis probe, reported the temporal changes in soluble $A \beta$ oligomer levels. In that study, consistent with previous studies $[85,86]$, a significant, age-dependent increase in $A \beta$ levels in TBS and formic acid extracts of brain tissues was found, and TBS extractable $A \beta$ was less than $1 \%$ of formic acid extractable $A \beta$. However, unlike previous studies using a 35-kDa-molecular-weight cutoff microdialysis probe $[85,86]$, a significant, age-dependent increase in interstitial fluid $A \beta$ levels was found by using the largerpore-sized microdialysis probe. The majority of the $A \beta$ in interstitial fluid was determined to be higher-molecularweight soluble $A \beta$ oligomers, which showed an agedependent increase relative to lower-molecular-weight $A \beta$ species. Temporal changes in soluble $A \beta$ oligomer levels in interstitial fluid and TBS brain extracts showed a significant positive correlation with formic acid $A \beta$ extract levels. Comparison of high- and low-molecular-weight interstitial fluid $A \beta$ levels at baseline and following acute treatment with a $\gamma$-secretase inhibitor showed slower clearance of higher-molecular-weight $\mathrm{A} \beta$ oligomers compared with low-molecular-weight $A \beta$ species.

Narayan and colleagues [88] have recently used singlemolecule imaging techniques to investigate interactions between $\mathrm{A} \beta$ peptides and hippocampal cell membranes and reported results indicating that $A \beta$ oligomers preferentially interact with membranes compared with $A \beta$ monomer, thereby providing support for the results observed in the microdialysis studies. Thus, this study, coupled with those of the temporal changes of A $\beta$ species in APP transgenic mice [85-87], does not resolve the controversy regarding the sink/source relationship between fibrillar and soluble A $\beta$ species.

The sink/source relationship between soluble and insoluble $A \beta$ pools is complex, not fully understood, and subject to ongoing debate. Two different forms of $A \beta$ plaques are present in the $\mathrm{AD}$ brain: vascular amyloid plaques that are primarily composed of $A \beta(1-40)$ and $A \beta$ plaques that are primarily composed of $\mathrm{A} \beta(1-42)$ [89]. In vitro studies have shown that fibrillar $A \beta(1-40)$ and $A \beta(1-42)$ are in equilibrium with soluble $A \beta[90,91]$ but that recycling of $A \beta(1-40)$ fibrils is significantly faster that $A \beta(1-42)$ fibrils [91]. Moreover, it has been reported that plaque deposition proceeds in two distinct kinetic phases: an initial, reversible deposition phase followed by a time-dependent irreversible deposition phase [92]. Furthermore, a recent study of the rates of formation of $A \beta$ oligomers and fibrils provided evidence that the formation of soluble $A \beta$ oligomers from monomeric $A \beta$ is catalyzed by fibrillar $A \beta$ [73]. This study not only indicated a mechanistic linkage between soluble $A \beta$ oligomers and fibrillar $A \beta$ but also provided evidence showing that fibrillar $A \beta$ can be a 'source' of soluble $A \beta$ via catalyzed oligomerization of $A \beta$ monomer rather than via a disaggregation process. This study also provided an alternative explanation for the study by Koffie and colleagues [93], who reported a halo of soluble $A \beta$ oligomers surrounding $A \beta$ plaques and proposed that $A \beta$ plaques were a possible source of soluble $A \beta$ oligomers.

Although precise details remain to be fully elucidated, collectively, over two decades of studies on the mechanisms of formation of oligomeric and fibrillar $A \beta$, the temporal distribution of $\mathrm{A} \beta$ species in vitro and in vivo, the age-dependent effect of $A \beta$ immunization, and the effects of subchronic and chronic suppression of $A \beta$ production upon in vivo $\mathrm{A} \beta$ plaque levels show a significant, age-dependent increase in brain levels of soluble $A \beta$ oligomers and deposited fibrillar $A \beta$. Collectively, the studies suggest that mature, dense-core $A \beta$ plaques are not in equilibrium to any significant extent with soluble pools of $A \beta$, but that $A \beta$ sequestered in the cell matrix and membranes and immature plaques is in equilibrium with soluble $A \beta$ pools, and that fibrillar $A \beta$ catalyzes $A \beta$ monomer oligomerization, giving rise to soluble $A \beta$ oligomers and growth of $\mathrm{A} \beta$ plaques. 


\section{Neuronal toxicity of amyloid-beta species}

Monomeric $A \beta$, primarily the $A \beta(1-40)$ and $A \beta(1-42)$ peptides, is produced in various cell types throughout the body and reported to have trophic properties in vitro $[94,95]$. There are no reports suggesting that monomeric $\mathrm{A} \beta$ possesses any direct cellular toxicity at physiologically relevant concentrations. Insoluble fibrillar aggregates of $A \beta$, vascular amyloid and $A \beta$ plaques, exhibit relatively low in vitro toxicity and have been proposed to be an in vivo mechanism for removal of the more toxic soluble $A \beta$ species [83,96,97]. It was first suggested in 1995 that soluble $A \beta$ species rather than fibrillar plaques could trigger neurotoxicity leading to $\mathrm{AD}$ [98], and in the subsequent decades, many studies have shown soluble $A \beta$ oligomers to be the most toxic $A \beta$ form, causing both acute synaptotoxicity and inducing neurodegenerative processes [5-10,99-102].

Low-picomolar levels of soluble $A \beta$ oligomers have been reported to have trophic properties in vitro [103-105], suggesting that therapeutic targeting of soluble $\mathrm{A} \beta$ oligomers may need to modulate oligomer levels versus completely sequestering or preventing formation of soluble $A \beta$ oligomers. However, the concentration of $A \beta 42$ at which enhancement of long-term potentiation (LTP) was observed in these studies was one to two orders of magnitude greater than levels of soluble $A \beta$ oligomers reported in the cerebrospinal fluid (CSF) of human patients with AD, and the concentration above which inhibition of LTP was observed was an order of magnitude greater than the total levels of soluble $A \beta$ species reported in the CSF of human patients with $\mathrm{AD}[65]$. Thus, the relevance of the reported in vitro trophic properties of soluble $A \beta$ oligomers to in vivo conditions remains to be established.

Soluble $A \beta$ oligomers bind with high affinity to synapses on a subset of hippocampal and cortical neurons [19,40,106-108], indicative of specific binding to discrete cell surface receptors. In rodent hippocampal slice preparations, synaptic binding leads to rapid inhibition of LTP $[19,40,109]$, and injection of various soluble $A \beta$ oligomer preparations directly into the rodent brain leads to reversible impairment of cognitive function $[31,33,110]$. This aberrant signaling also causes accumulated biochemical damage within neurons [100,111,112], such as hyperphosphorylation of tau [100,111-113], suggesting a linkage between $A \beta$ and tau pathologies [114-116]. Soluble A $\beta$ oligomers have been isolated from extracts of postmortem AD brain tissue and from transgenic AD animal models [37,52,117-119] and have been reported to be elevated in human $\mathrm{AD}$ brain relative to non-demented older patients $[59,61,62,65,119-124]$. Importantly, a recent study suggests a correlation between CSF levels of soluble $A \beta$ oligomers and cognitive deficits in human patients with AD $[61,65]$. These findings support the view that soluble $A \beta$ oligomers interfere acutely with normal synaptic functions and contribute significantly to the memory loss and cognitive dysfunction characteristic of AD.

\section{Structure and activity of soluble amyloid-beta oligomer species}

There is substantial ongoing debate and research concerning the structure and activity of soluble $A \beta$ species $[5,7-9,33,41,52,72,99,125-127]$. Various soluble $A \beta$ oligomer species have been reported to display synaptic toxicity or induce cognitive deficits, including dimers $[33,35,128,129]$, trimers [32], dodecamers [33,37,40], and larger soluble $A \beta$ oligomers with molecular weights of 90 to $650 \mathrm{kDa}$ (20 to 150 mers) [19,130,131]. Unfortunately, the different methodologies for the preparation, characterization, and evaluation of soluble $A \beta$ oligomer species by various research groups impede a direct comparison of the results reported, and few studies have directly compared the toxicities of different soluble $A \beta$ species while using the same techniques.

Two studies have reported the comparative toxicities of different soluble $A \beta$ oligomer species by using $\mathrm{LDH}$ (lactate dehydrogenase release) and MTT (oxidoreductase activity) cell viability assays. Deshpande and colleagues [45] examined the relative toxicities of purified spherical $A \beta(1-42)$ oligomers [50], ADDLs [132], and fibrils [50]. However, because solutions of soluble $A \beta$ oligomers in the neurobasal medium used in this study have been shown to change with time [19], it is not possible to draw definitive structure-activity conclusions from the results of this study. In the second study, Ono and colleagues [133] reported relative toxicities of purified, cross-linked $A \beta(1-40)$ dimers, trimers, and tetramers, which were shown to be relatively stable under the assay conditions. In an MTT assay, half maximal effective concentration values were 67.3, 41.6, 24.5, 20.5, and 57.6 $\mu \mathrm{M}$, respectively, for monomer, dimer, trimer, tetramer, and fibrils. Comparable toxicity was obtained in an LDH assay. The micromolar concentrations of $A \beta$ species used in this study were approximately six orders of magnitude greater than in vivo $\mathrm{A} \beta$ concentrations, and the relevance of cell culture MTT-type assays to the in vivo synaptotoxicity of $A \beta$ species has been questioned [134]. Therefore, the results of the study by Ono and colleagues provide little understanding of the relative in vivo toxicities of soluble $\mathrm{A} \beta$ species.

More recently, cognitive effects in vivo were assessed in rats by using the alternating lever cyclic ratio assay following intracerebroventricular (ICV) injections of cell- and synthetically derived soluble $A \beta$ oligomers [33]. Monomer and low-n-mer soluble $A \beta$ oligomers derived from 7PA2 cells [29,135-137], trimer and a dodecameric species (A $\beta * 56)$ extracted from $\operatorname{Tg} 2576$ mouse brain [37], and synthetic soluble $A \beta$ oligomers (ADDLs) [43] 
were compared in this study. Injection of conditioned media from 7PA2 cells caused significant cognitive deficits. Evaluation of size exclusion chromatography (SEC)enriched dimer or trimer fractions of 7PA2 cell-conditioned media showed significant cognitive deficits following injection of dimer-enriched fractions but a non-significant effect upon injection of trimer-enriched fractions. SEC-purified monomer had no effect. $A \beta$ monomer was the predominant $\mathrm{A} \beta$ species in unfractionated 7PA2 conditioned media, and the amounts of dimer and trimer injected in the dimer- and trimer-enriched fractions were considerably greater than the amounts injected in unfractionated conditioned media. However, cognitive effects following injection of unfractionated conditioned media were comparable to or exceeded the observed effects following treatment with dimer- and trimer-enriched fractions. Thus, there is an inherent ambiguity regarding the results reported for 7PA2-derived $A \beta$ species that is difficult to explain. One possible explanation is that a higher-order soluble $A \beta$ oligomer species contributes to the cognitive deficits observed upon injection of unfractionated 7PA2 conditioned media and is a more potent inhibitor of cognitive function than $A \beta$ dimer or trimer species or both. Another possible explanation is that combinations of different soluble $A \beta$ oligomer species, perhaps interacting differently with different neuronal receptors, have an additive or synergistic toxicological effect. Trimers extracted from aged Tg2576 mouse brain also failed to elicit significant cognitive deficits. However, consistent with other in vivo efficacy studies [37], a dodecameric soluble $A \beta$ oligomer extracted from aged Tg2576 mouse brain $(\mathrm{A} \beta * 56)$ caused significant cognitive deficits. Synthetic soluble A $\beta$ oligomers (ADDLs) also caused cognitive deficits following ICV injection. The results of this study show that ICV injection of soluble $A \beta$ oligomers from different sources causes cognitive deficits in wild-type rats and that these deficits are reversible. The results of the study show that soluble $A \beta$ oligomer containing conditioned media of 7PA2 cells is more potent than solutions of $A \beta * 56$ obtained from aged Tg2576 mouse brains or solutions of synthetically prepared soluble $A \beta$ oligomers (ADDLs). However, because it is not possible to quantitatively characterize the exact nature or distribution of soluble $\mathrm{A} \beta$ species in these different preparations, it is not possible to draw definitive conclusions from this study regarding the structure-activity relationships between individual soluble $A \beta$ oligomer species.

In a more recent study, Moreth and colleagues [19] prepared, characterized, and evaluated the hippocampal binding and effects on neurotransmission of spheroidal, protofibrillar, and fibrillar $A \beta$ aggregates. Under the conditions used to test for hippocampal binding and neurotransmission, the different species where shown to be relatively unchanged. Monomeric and fibrillar $A \beta$ did not bind to mature hippocampal neurons (DIV21) or effect neurotransmission at concentrations as high as $1 \mu \mathrm{M}$. In contrast, spheroidal and protofibrillar $\mathrm{A} \beta$ aggregates displayed punctate binding to mature hippocampal neurons and impaired neurotransmission with nanomolar potency. Significantly, the mode of impairment of neurotransmission was different for spheroidal $A \beta$ aggregates, which impaired LTP at $30 \mathrm{nM}$, compared with protofibrillar aggregates, which impaired basal neurotransmission at $100 \mathrm{nM}$. Spheroidal A $\beta$ aggregates had no effect on basal neurotransmission at concentrations as high as $100 \mathrm{nM}$. Although this study was unable to address the comparative neurotoxicity of discrete soluble $A \beta$ oligomers, it did show that different forms of soluble $A \beta$ oligomers can trigger distinct neuronal activities.

At this point, the exact structures of the toxicologically relevant soluble $A \beta$ oligomer species have not been determined to the complete exclusion of other possible structures, and analytical tools do not exist to characterize the $\mathrm{A} \beta$ oligomers that form at concentrations in the $\mathrm{AD}$ brain $[44,138]$. The numerous studies reporting neuronal toxicity for different soluble $A \beta$ oligomers support the conclusion that multiple soluble $A \beta$ oligomer species exhibit neuronal toxicity, rather than a single, discrete toxic species. This suggestion of multiple toxic soluble $A \beta$ oligomer species may also explain the plethora of reported neuronal receptors that mediate the effects of soluble $A \beta$ oligomers (Table 1) [139-165], a discussion of which is well beyond the scope of this review. (See the perspective of Benilova and De Strooper [166] for a good introduction to this complex and controversial field of study.)

Despite recognition that soluble $A \beta$ oligomers are key structures causing $\mathrm{AD}$ memory malfunction and cognitive deficits, drug discovery efforts targeting these species have been hampered by perceived technical difficulties of generating physiologically relevant preparations of synthetic soluble $\mathrm{A} \beta$ oligomers and by differing terminologies and methodologies used by various researchers [167]. However, well-characterized and documented preparations of synthetic soluble $\mathrm{A} \beta$ oligomers have been reported by numerous researchers $[19,40,43,95,100,107,108,111,168-170]$ that generate soluble $A \beta$ oligomers with little or no detectable fibrillar $A \beta$ species. With the availability of a number of welldocumented preparations of different soluble $A \beta$ oligomer species and tools for comparative characterization, it is hoped that additional side-by-side testing of various soluble $\mathrm{A} \beta$ oligomer preparations in different toxicity paradigms such as reversal of basal neurotransmission, LTP inhibition, changes in AMPA receptor trafficking, tau phosphorylation, and loss of dendritic spines $[19,108,109,170]$ will be conducted and reported.

\section{Amyloid-beta immunotherapies in development}

Successful immunotherapies developed for most diseases rely upon antibodies that possess high selectivity for a 
Table 1 Reported receptors that bind or mediate the toxicity of soluble amyloid-beta oligomers

\begin{tabular}{lll}
\hline Reported receptor & & \\
\hline Amylin receptor [139] & NMDA receptor [140-144] & Sortilin [145] \\
P53-Bax cell death pathway [146] & CAMP/PKA/CREB-signaling pathway [147,148] & Tau protein kinase 1/glycogen synthase kinase-3ß [51] \\
c-Jun N-terminal kinase [149] & a-synuclein [150] & P/Q-type calcium currents [49] \\
Cyclin-dependent kinase 5 [149] & EphB2 [151] & Dynamin and RhoA [152] \\
mGluR, mGluR5, mGluR2 [108,142,149,153,154] & TNFa [155] & Cofilin [140] \\
p38 mitogen-activated protein kinase [149] & PrPc [154,156-159] & Calcineurin [160-162] \\
a 7-nicotinic receptors [105] & AMPA [160] & Brain-derived neurotrophic factor [131] \\
Human LilrB2 [163] & Insulin receptor [164] & Sigma 2 receptor [165] \\
STI1 [156] & &
\end{tabular}

NMDA, N-methyl-D-aspartate; TNFa, tumor necrosis factor alpha.

particular target antigen connected to the disease. However, all $\mathrm{A} \beta$-directed immunotherapies currently in clinical development are based on non-selective antibodies that bind multiple $A \beta$ species. Treatment with nonselective anti-A $\beta$ antibodies that bind monomeric or oligomeric $A \beta$ (or both) potentially could succeed in a prodromal treatment paradigm by reducing total brain A $\beta$ to levels below the toxicological threshold. However, given the high concentrations of monomeric and fibrillar $\mathrm{A} \beta$ compared with soluble $\mathrm{A} \beta$ oligomers in the $\mathrm{AD}$ brain [57-65] and the low levels of antibodies that penetrate the brain from the periphery [171], it will be very challenging for non-selective anti-A $\beta$ antibodies that bind monomeric or fibrillar $A \beta$ (or both) to show efficacy when administered to patients with mild cognitive impairment or mild-to-moderate AD. In contrast, the acute synaptic toxicity and very low brain levels of soluble $A \beta$ oligomers suggest that anti-A $\beta$ antibodies with selective affinity for soluble $A \beta$ oligomers could provide therapeutic benefit for patients with mild cognitive impairment or mild-to-moderate AD.

It might seem difficult to generate a monoclonal antibody that does not bind monomeric or fibrillar $A \beta$ yet possesses high affinity for structurally heterogeneous soluble $A \beta$ oligomers. However, monomeric, oligomeric, and fibrillar $A \beta$ species have been reported to have distinct conformational characteristics [172-175]. Moreover, antibodies with selective affinity for soluble $A \beta$ oligomers versus monomeric and fibrillar $A \beta$ have been reported $[9,176,177]$. These several examples of antibodies suggest that therapeutically relevant soluble $\mathrm{A} \beta$ oligomer-directed antibodies are indeed feasible.

A number of recent publications have reviewed $A \beta$ immunotherapies currently in clinical trials, with an emphasis on the efficacy of the drugs for treating $\mathrm{AD}$ [178-187], and the clinical results will not be presented in this review, with the exception of an analysis of the brain levels of solanezumab and bapineuzumab in recently reported clinical trials. Instead, this review will focus on a discussion of the comparative affinities of the $\mathrm{A} \beta$ antibodies in clinical development for monomeric, soluble oligomeric, and fibrillar $\mathrm{A} \beta$ species. Notably, none of the $A \beta$ immunotherapies currently in clinical development selectively targets soluble $\mathrm{A} \beta$ oligomers, as discussed below and summarized in Table 2 .

\section{Solanezumab}

Solanezumab is unique among $A \beta$ antibodies currently in clinical development because it does not bind fibrillar A $\beta$. Solanezumab is a humanized, IgG1 monoclonal antibody derived from the murine monoclonal antibody, 266. 266 was selected for its high-affinity binding to soluble $A \beta$, although the exact nature of the soluble $A \beta$ it binds was not reported. It has been suggested that 266 is a conformation-specific antibody that solely recognizes soluble $A \beta$ and readily binds monomeric $A \beta$ [188-190], without binding APP or the C-terminal APP cleavage product of $\alpha$-secretase [189]. It has been reported that 266 selectively sequesters $A \beta$ monomer and dimer in the periphery of 3-month-old APP transgenic mice [190], and definitive evidence for 266 binding of monomeric $A \beta$ has been reported [191]. A study using crossed-linked soluble A $\beta$ oligomers showed 266 could immunoprecipate A $\beta$ monomer and low-molecular-weight dimer, trimer, and possibly tetramer [192]. A study involving a competitive ELISA showed that 266 had a seven-fold higher affinity for monomeric $A \beta$ than synthetic soluble $A \beta$ oligomers [193]. Several studies have shown that 266 does not bind A $\beta$ plaques or vascular amyloid $[188,190,194]$. Thus, according to the available data, solanezumab and 266 bind monomeric and lower-molecular-weight soluble $\mathrm{A} \beta$ oligomer species, with a preference for monomeric $A \beta$, but do not bind fibrillar $\mathrm{A} \beta$ species.

Clinical trial pharmacokinetic data for brain levels of solanezumab have not been reported. However, target engagement data reported for the phase 2, multiple ascending-dose clinical trials (Table 3) [183] provide a possible understanding of the lack of efficacy of solanezumab in clinical 
Table 2 Comparison of binding affinities of amyloid-beta $(A \beta)$ immunotherapies in development for $A \beta$ monomer, soluble $A \beta$ oligomers, and fibrillar $A \beta$

\begin{tabular}{lccc}
\hline & \multicolumn{3}{c}{ Binding affinity $^{\mathbf{a}}$} \\
\cline { 2 - 4 } $\mathbf{A} \boldsymbol{\beta}$ antibody & $\mathbf{A} \boldsymbol{\beta}$ monomer & $\mathbf{A} \boldsymbol{\beta}$ oligomers & $\mathbf{A} \boldsymbol{\beta}$ plaque \\
\hline Solanezumab/266 & +++ & ++ & - \\
Bapineuzumab/3D6 & ++ & +++ & +++ \\
Crenezumab & ++ & +++ & ++ \\
Ponezumab/D-2H6 & ++ & ++ & +++ \\
BiiB037/NI-101.11 & + & +++ & +++ \\
BAN2401/mAb158 & - & +++ & +++ \\
Gantenerumab & + & ++ & +++ \\
SAR228810/13C3 & - & +++ & +++ \\
\hline
\end{tabular}

${ }^{a}$ Based on published patent applications or peer-reviewed scientific publications. + , low affinity binding; ++ , moderate affinity binding; +++ , high affinity binding; - , very low affinity or no binding.

trials [186]. The data for the $400 \mathrm{mg} / \mathrm{month}$ and $400 \mathrm{mg} /$ week dose levels show approximately a 2.7 -fold increase in solanezumab bound $\mathrm{A} \beta$ at the higher dose level $(5,858$ versus $15,825 \mathrm{pg} / \mathrm{mL}$ total $\mathrm{A} \beta 40$ and $\mathrm{A} \beta 42$ ) [183], showing that there was incomplete target engagement at the 400 $\mathrm{mg} / \mathrm{month}$ dose level used in the pivotal phase 3 trials. Solanezumab binds $A \beta$ monomer with higher affinity than soluble $A \beta$ oligomers and does not bind or disaggregate fibrillar $\mathrm{A} \beta$. Because incomplete target engagement occurred at the dose level used in the phase 3 trials, it is unlikely any solanezumab was available to bind soluble $\mathrm{A} \beta$ oligomers; thus, the lack of efficacy of solanezumab at the dose levels used in the phase 3 clinical trials is not unexpected.

\section{Bapineuzumab}

Bapineuzumab is a humanized, IgG1 monoclonal antibody derived from the murine antibody, 3D6. Bapineuzumab and 3D6 are non-selective $\mathrm{A} \beta$ antibodies that bind with high affinity to monomeric A $\beta$ [192], soluble A $\beta$ oligomers [170], and fibrillar A $\beta$ [195-197] but do not recognize APP or the product of $\beta$-secretase

Table 3 Mean cerebrospinal fluid levels of bound and unbound amyloid-beta (A 3$) 40$ and $A \beta 42$ in Alzheimer's disease patients treated with solanezumab

\begin{tabular}{|c|c|c|}
\hline Solanezumab dose $^{a}$ & $\begin{array}{c}\text { Mean CSF A } \beta 40, \\
\mathrm{pg} / \mathrm{mL}^{\mathrm{b}}\end{array}$ & $\begin{array}{c}\text { Mean CSF A }{ }^{A} \beta 42 \\
\mathrm{pg} / \mathrm{mL}^{\mathrm{b}}\end{array}$ \\
\hline $100 \mathrm{mg}$ Q4W & 625 & 0.0 \\
\hline $100 \mathrm{mg} \mathrm{QW}$ & 3,750 & 275 \\
\hline 400 mg Q4W & 5,625 & 233 \\
\hline 400 mg QW & 15,000 & 825 \\
\hline
\end{tabular}

${ }^{\mathrm{a} S o l a n e z u m a b}$ phase 2 MAD data [183]. ${ }^{\mathrm{b}}$ Mean $\mathrm{pg} / \mathrm{mL}$ levels of total bound and unbound $A \beta 40$ and $A \beta 42$ in cerebrospinal fluid (CSF) of treated patients, derived from Figures $3 \mathrm{~A}$ and $3 \mathrm{~B}$ reported by Farlow and colleagues [183]. Q4W, monthly dosing; QW, weekly dosing. cleavage of APP [198]. In a competitive ELISA assay study, $3 \mathrm{D} 6$ was found to bind monomeric $\mathrm{A} \beta$ and synthetic soluble A $\beta$ oligomers with similar affinity [193]. Babineuzumab/3D6 bind vascular amyloid and $A \beta$ plaques in hAPP transgenic mice brains and human AD brains and clear vascular amyloid and $\mathrm{A} \beta$ plaques in hAPP transgenic mice brains [188,197,199-201]. Thus, bapineuzumab and 3D6 do not distinguish between the various $A \beta$ species in the $A D$ brain.

Mean CSF levels of bapineuzumab reported in the phase 2, multiple ascending-dose pharmacokinetic clinical studies were $4.9,18.1,27.2$, and $44.7 \mathrm{ng} / \mathrm{mL}$, respectively, at dose levels of $0.15,0.5,1.0$, and $2 \mathrm{mg} / \mathrm{kg}$ ( $\mathrm{six}$ infusions, 13 weeks apart) [202], which upon conversion to molar concentrations are $0.03,0.12,0.18$, and 0.3 $\mathrm{pmol} / \mathrm{mL}$, respectively, based on a bapineuzumab molecular weight of $150 \mathrm{kDa}$. In the same studies, placebotreated mean CSF levels of $A \beta(1-42), A \beta(x-42)$, and $\mathrm{A} \beta(1-40)$ were $376.7,537.9$, and $6,705.4 \mathrm{pg} / \mathrm{mL}$, respectively, which upon conversion to molar concentrations are $0.08,0.12$, and $1.55 \mathrm{pmol} / \mathrm{mL}$, respectively (assuming the molecular weight of $A \beta(x-42)$ is the same as that of $A \beta(1-40))$. The highest bapineuzumab dose level in phase 3 pivotal trials was $1 \mathrm{mg} / \mathrm{kg}$ (six infusions, once every 13 weeks) [187]. Thus, the total mean A $\beta$ CSF levels were approximately an order of magnitude greater than mean levels of bapineuzumab. Because bapineuzumab binds monomeric $A \beta$ with similar affinity to soluble $A \beta$ oligomers and fibrillar $A \beta$ and because $A \beta$ soluble oligomer levels are orders of magnitude less than $A \beta$ monomer and fibrils levels in the AD brain [58-65], it is clear that bapineuzumab was not dosed high enough in the pivotal phase 3 trials to effectively sequester soluble $\mathrm{A} \beta$ oligomers. Thus, the absence of efficacy of bapineuzumab in clinical trials is not unexpected.

\section{Crenezumab}

Crenezumab (MABT5102A or MABT) is a humanized, IgG4 monoclonal anti-A $\beta$ antibody that was engineered to reduce $\mathrm{Fc} \gamma$ receptor-mediated microglia activation and minimize adverse effects due to vasogenic edema and cerebral microhemorrhage [203,204]. Crenezumab binds $A \beta$ monomer, soluble $A \beta$ oligomers, and fibrillar $\mathrm{A} \beta$ with similar affinities and binds plaques in hAPP transgenic mice and human AD brain tissues [203,204]. Similar binding of crenezumab to human $A \beta(1-40)$ and $\mathrm{A} \beta(1-42)$ peptides and mouse/rat $\mathrm{A} \beta(1-42)$ has also been reported [204]. These results indicate that crenezumab does not possess selectivity for different $A \beta$ species [204]. Consistent with a lack of selectivity, crenezumab prevents $A \beta$ aggregation and disaggregates pre-aggregated $\mathrm{A} \beta$ species. Thus, crenezumab is similar to bapineuzumab with respect to non-selective binding of monomeric, oligomeric, and fibrillar $A \beta$ species. 


\section{Ponezumab}

Ponezumab is a humanized, modified IgG2 monoclonal antibody derived from the murine monoclonal antibody, 2H6. This progenitor murine antibody binds to monomeric $A \beta(1-40)$ with high affinity but does not bind to $A \beta(1-16), A \beta(1-28), A \beta(1-38), A \beta(1-42)$, or $A \beta(1-43)$ [205]. Intracranial injection of $2 \mathrm{H} 6$ and its deglycosylated form into plaque-rich, 20-month-old Tg2576 mice followed by histological analysis of total $A \beta$ load in the hippocampus and frontal cortex showed significant plaque reduction in both regions compared with control tissues [206], suggesting that these antibodies bind and disaggregate fibrillar amyloid. More recent studies show that ponezumab labels amyloid plaques in 14-month-old Tg2576 mouse and human AD brains [207], demonstrating binding to fibrillar $A \beta$. Binding of ponezumab to Tg2576 mouse brain plaque was comparable to the known high-affinity binding of the $\mathrm{N}$-terminal $\mathrm{A} \beta$ antibody 6 E10. Ponezumab was also reported to bind monomeric, oligomeric, and fibrillar forms of $\mathrm{A} \beta(1-40)$ but did not show appreciable binding to monomeric, oligomeric, or fibrillar forms of $\mathrm{A} \beta(1-42)$ [207]. Thus, although ponezumab displays selectivity for $A \beta(1-40)$ versus other $A \beta$ peptide isoforms, it is relatively nonselective for monomeric, soluble oligomeric, or fibrillar A $\beta$ species.

\section{BiiB037}

BiiB037 is a human IgG1 monoclonal antibody derived from a patient with $\mathrm{AD}$ by using reverse translational medicine methodology [208]. In vitro BiiB037 binds fibrillar $A \beta(1-42)$ with high affinity but does not bind soluble $A \beta(1-40)$ [209]. Although explicit details of the binding characteristics of BiiB037 have not been publicly disclosed, results reported by Dunstan and colleagues [209] and data in the patent covering BiiB037 [208] suggest that BiiB037 is very similar, or identical, to antibody NI-101.11, which binds with high affinity to $A \beta$ plaques in human AD brain tissue samples [208]. Such binding is not blocked by monomeric $A \beta(1-16)$ or $A \beta(1-42)$, showing selective affinity for fibrillar $A \beta$ versus $A \beta$ monomers [208]. Comparison of binding affinity in an A $\beta$ plate-based ELISA showed greater than 100-foldhigher affinity for fibrillar $A \beta(1-42)$ than for monomeric $\mathrm{A} \beta(1-42)$ [208]. SEC studies showed that NI-101.11 bound to fluorescein isothiocyanate-labeled $A \beta(1-42)$ in the early-eluting peak (non-retained, large $A \beta$ species) but that little binding was associated with the retained, low-molecular-weight A $\beta$ peak [208]. Many researchers have deployed SEC to separate higher-molecular-weight soluble $A \beta$ oligomer species from low-molecular-weight A $\beta$ species $[20,44,130,155,210-212]$, and in all cases the higher-molecular-weight, early-eluting peak contains soluble $A \beta$ oligomers or $A \beta$ protofibrils or both. Together these results show that NI-101.11 binds soluble A $\beta$ oligomers and protofibrils in addition to fibrillar $A \beta$. Consistent with this conclusion is the finding that NI-101.11 inhibits the formation of $A \beta$ fibrils in vitro [208]. Thus, according to the available data, BiiB037/NI-101.11 binds soluble $A \beta$ oligomers and fibrillar $A \beta$ with high affinity and binds monomeric $A \beta$ with low affinity.

\section{BAN2401}

BAN2401 is a humanized, IgG2a monoclonal antibody derived from the murine precursor mAb158, which was raised against $A \beta$ protofibrils generated from $A \beta(1-42)$ $\mathrm{E} 22 \mathrm{G}$, the arctic mutant of the $\mathrm{A} \beta$ peptide [210]. Although mAb158 is claimed to be a 'highly protofibrilselective monoclonal antibody' [213], published data show that it binds fibrillar $\mathrm{A} \beta$ with a high affinity similar to that of protofibrils in a dot-blot assay [210,214] and binds fibrillar deposits in transgenic APP-ArcSwe mice brain (see Figure S2 in [213]). In a more recent study, mAb158 was shown to bind soluble A $\beta$ oligomer fractions in the molecular weight range of 80 to $2,000 \mathrm{kDa}$ under conditions in which protofibrillar species were not detected [119]. In this study, mAb158 showed essentially no binding to low-molecular-weight $\mathrm{A} \beta$ oligomeric species in the molecular weight range of 5 to $80 \mathrm{kDa}$. A lack of binding to low-molecular-weight $A \beta$ species - monomeric to tetrameric $A \beta(1-40), A \beta(1-16)$, and $A \beta(17-40)$ was found in an earlier study [213]. Thus, mAb158 binds higher-molecular-weight $A \beta$ aggregates, including soluble $\mathrm{A} \beta$ oligomers, protofibrils, and fibrillar $\mathrm{A} \beta$. Consistent with the binding of $\mathrm{mAb} 158$ to fibrillar $\mathrm{A} \beta$, intracranial injection of $\mathrm{mA} \beta 158$ in a transgenic APP-Swe mouse model was reported to cause a significant reduction in plaque burden by 72 hours after injection [214]. In a subsequent study in a transgenic APP-ArcSwe mouse model [213], 4 months of weekly intraperitoneal injections of mAb158 to 9- to 10-month-old mice with modest plaque burden resulted in a significant reduction of $\mathrm{A} \beta$ protofibrils (74\%) but no significant reduction in total soluble or insoluble $\mathrm{A} \beta$ levels in the cerebral cortex or hippocampus as determined by immunohistochemical analysis. The differences in effects of mAb158 on existing plaque burden in these two studies may be due to different administration routes (direct intracranial versus peripheral injections). As noted by Lord and colleagues [213], it may also be attributable to the APP-ArcSwe mouse model used in the more recent study, a model that exhibits more highly insoluble densecore plaques, preventable only by early and continuous A $\beta$ immunotherapy. Thus, mAb158/BAN2401 binds higher-molecular-weight soluble $A \beta$ oligomers (referred to as protofibrils in the mAb158 literature) and fibrillar $\mathrm{A} \beta$ with high affinity and has low affinity for binding monomeric $A \beta$ and lower-molecular-weight soluble $A \beta$ oligomers. 


\section{Gantenerumab}

Gantenerumab is a humanized monoclonal antibody that was optimized to have high-affinity binding of fibrillar $\mathrm{A} \beta$ and shows high-affinity binding to diffuse and dense-core plaques in human AD brain and APP transgenic mouse brain tissues [215]. Gantenerumab also binds soluble A $\beta$ oligomers with high affinity and, to a lesser extent, $A \beta$ monomer. The reported binding constants (Kds) for gantenerumab binding to fibrillar $A \beta$, soluble $A \beta$ oligomers, and $\mathrm{A} \beta$ monomer are $0.6,1.2$, and $17 \mathrm{nM}$, respectively [215]. The dissociation constants (kds) for gantenerumab$\mathrm{A} \beta$ complexes were reported to be $2.8 \times 10^{-4}, 4.9 \times 10^{-4}$, and $1.2 \times 10^{-2}$, respectively, for fibrillar $A \beta, A \beta$ oligomers, and $A \beta$ monomer [215], suggesting a more rapid exchange of antibody-monomer complex compared with antibodyfibril or oligomer complexes. The selective affinity of gantenerumab for fibrillar $A \beta$ and soluble $A \beta$ oligomers suggests that it may be similar to BiiB013/NI-101.11 and BAN2401/mAb158. Consistent with its high-affinity binding to fibrillar $A \beta$, gantenerumab caused a significant, dose-dependent reduction in amyloid plaques in human AD brain tissue [215]. Immunohistochemical analysis of PS2APP transgenic mice brain tissue 3 days after intravenous injection of gantenerumab showed dose-dependent binding to amyloid plaques. Significantly, pharmacokinetic analysis in PS2APP transgenic mice following a single intravenous bolus dose showed sustained binding of gantenerumab to plaques in the brain for up to 9 weeks postdosing, even though there was no detectable antibody in the plasma beyond 3 weeks post-dosing [215]. In a chronic treatment study in 5- to 6-month-old PS2APP transgenic mice, gantenerumab caused a significant reduction in preexisting small plaques; however, there was an increase in larger plaques [215]. These results suggest that gantenerumab causes a redistribution of $A \beta$ from small plaques to large plaques, possibly via disaggregation of smaller, less mature plaques. Gantenerumab-mediated disaggregation of existing plaques is consistent with the observations of vasogenic edema and microhemorrhage in human patients with AD treated with gantenerumab in clinical trials [216]. Thus, gantenerumab non-selectively binds soluble $A \beta$ oligomers and fibrillar $A \beta$ with similar high affinity in comparison with its lower-affinity binding of monomeric $A \beta$.

\section{SAR228810}

SAR228810 is a humanized, monoclonal antibody derived from the murine monoclonal antibody $13 \mathrm{C} 3$, which was raised to $A \beta$ protofibrils derived from $A \beta(1-42)[217,218]$. The humanized antibody was engineered into an IgG4 framework to reduce binding to $\mathrm{F} c \gamma$ and $\mathrm{C} 1 \mathrm{q}$ receptors and decrease risks of amyloid-related imaging abnormalities [219]. Although specific binding characteristics of SAR228810 have not been publicly disclosed, results reported by Pradier and colleagues [219] and data in the patent application claiming humanized variants of 13C3 [220] suggest that SAR228810 is very similar, or identical, to antibody LP09027 [220]. Antibody 13C3 and its humanized variants are reported to bind with higher affinity to SEC-separated protofibrillar $A \beta(1-42)$ than to low-molecular-weight $A \beta(1-42)$ [217,218,220]. As noted previously, many researchers have used SEC to separate higher-molecular-weight soluble $A \beta$ oligomer species from low-molecular-weight $A \beta$ species $[20,44,130,155,210-212]$, and in all cases the highermolecular-weight, early-eluting peak contains soluble $A \beta$ oligomers or $A \beta$ protofibrils or both. Moreover, as reported by Hepler and colleagues [44], the lowermolecular-weight, late-eluting peak contains predominately monomeric $\mathrm{A} \beta$. Thus, these data show that $13 \mathrm{C} 3$ and its humanized variants selectively bind $A \beta$ oligomers or protofibrils (or both) compared with monomeric $A \beta$. In competitive ELISA experiments, monomeric $A \beta(1-28)$, $A \beta(1-16)$, or $A \beta(25-35)$ does not prevent binding of humanized 13C3 to plates coated with $A \beta(1-42)$ [220]. Ravetch and Fukuyama [218] reported that $13 \mathrm{C} 3$ binds only to the higher-molecular-weight $\mathrm{A} \beta$ species contained in the supernatants from 7PA2 cells, in contrast to the non-selective $A \beta$ antibody 4G8 that binds low-, medium-, and higher-molecular-weight $A \beta$ species. Collectively, these data show the selectivity of $13 \mathrm{C} 3$ for higher-molecular-weight $A \beta$ oligomers versus lowermolecular-weight $\mathrm{A} \beta$ oligomers and monomer. Antibody $13 C 3$ was shown to bind fibrillar $A \beta(1-42)$ and label $\mathrm{A} \beta$ deposits in human $\mathrm{AD}$ brain tissue samples [218]. Antibody LP09027 was shown to bind fibrillar $\mathrm{A} \beta$ in vitro and to label $\mathrm{AB}$ deposits in brain sections from APP-PS1 mice [220]. Thus, the reported data suggest that 13C3/SAR228810 is very similar to mAb158/ BAN2401 and binds higher-molecular-weight soluble $\mathrm{A} \beta$ oligomers (referred to as protofibrils in the 13C3/ SAR228810 literature) and fibrillar $A \beta$ with high affinity and has low affinity for binding monomeric $A \beta$ and lower-molecular-weight soluble A $\beta$ oligomers.

\section{Conclusions}

The lack of efficacy observed for $\mathrm{A} \beta$ immunotherapies in clinical development is not unexpected given their lack of selectivity for soluble $A \beta$ oligomers compared with monomeric or fibrillar $A \beta$ and given the tremendous quantities of monomeric or fibrillar $A \beta$ in the $A D$ brain relative to soluble $A \beta$ oligomers. $A \beta$ antibodies optimized to bind soluble $A \beta$ oligomers selectively are much more likely to succeed in AD clinical trials and should be aggressively pursued.

The prediction that immunotherapies targeting soluble A $\beta$ oligomers will elicit clinical benefit is supported by studies of human $A \beta$ autoantibodies, of which only a subset appears to be disease-protective (in particular, the 
subset that preferentially recognizes $\mathrm{A} \beta$ oligomers) [221-223]. Thus, immunotherapeutics with high selectivity for soluble $A \beta$ oligomers, which resemble these protective auto-antibodies, are expected to deliver a clinical advantage compared with the non-selective immunotherapies in clinical development.

Studies have demonstrated that antibodies with selective affinity for soluble $A \beta$ oligomers can block soluble A $\beta$ oligomer-mediated synaptotoxicity in cell cultures $[108,224]$ and rapidly normalize memory deficits in transgenic AD mouse models [176]. These findings support the concept that antibodies with selective affinity for soluble $A \beta$ oligomers may be a more effective therapeutic strategy than antibodies with high affinity for monomeric or fibrillar $\mathrm{A} \beta$ or both.

\section{Abbreviations}

AD: Alzheimer's disease; ADDL: Amyloid-derived diffusible ligand;

APP: Amyloid precursor protein; A $\beta$ : Amyloid-beta; CSF: Cerebrospinal fluid; ELISA: Enzyme-linked immunosorbent assay; ICV: Intracerebroventricular;

LDH: Lactate dehydrogenase release; LTP: Long-term potentiation;

SDS: Sodium dodecyl sulfate; SEC: Size exclusion chromatography; TBS: Trisbuffered saline.

\section{Competing interests}

All authors are employees or paid consultants of Acumen Pharmaceuticals, Inc. and own stock or stock options of this company.

\section{Authors' contributions}

All authors read and approved the final manuscript.

\section{Published: 09 Jul 2014}

\section{References}

1. Alzheimer's Disease International, World Alzheimer Report, 2010: The Global Economic Impact of Dementia. Alzheimer's Disease International 2010, [http://www.alz.co.uk/research/files/WorldAlzheimerReport2010.pdf].

2. Bleiler TW: 2013 Alzheimer's disease facts and figures. Alzheimers Dement 2013, 9:208-245 [http://www.alz.org/downloads/facts_figures_2013.pdf].

3. Selkoe DJ: Alzheimer's disease results from the cerebral accumulation and cytotoxicity of amyloid $\beta$-protein. J Alzheimers Dis 2001, 3:75-80.

4. Walsh DM, Selkoe DJ: A $\beta$ oligomers - a decade of discovery. J Neurochem 2007, 101:1172-1184.

5. Roychaudhuri R, Yang M, Hoshi MM, Teplow DB: Amyloid $\beta$-protein assembly and Alzheimer disease. J Biol Chem 2009, 284:4749-4753.

6. Ondrejcak T, Klyubin I, Hu N-W, Barry AE, Cullen WK, Rowan MJ: Alzheimer's disease amyloid $\beta$-protein and synaptic function. Neuromol Med 2010, 12:13-26.

7. Sakono M, Zako T: Amyloid oligomers: formation and toxicity of $A \beta$ oligomers. FEBS J 2010, 277:1348-1358.

8. Ferreira ST, Klein WL: The $A \beta$ oligomer hypothesis for synapse failure and memory loss in Alzheimer's disease. Neurobiol Learn Mem 2011, 96:529-543.

9. Benilova I, Karran E, De Strooper B: The toxic A $\beta$ oligomer and Alzheimer's disease: an emperor in need of clothes. Nat Neurosci 2012, 15:349-357.

10. Hayden EY, Teplow DB: Amyloid $\beta$-protein oligomers and Alzheimer's disease. Alzheimers Res Ther 2013, 5:60.

11. Wong CW, Quaranta V, Glenner GG: Neuritic plaques and cerebrovascular amyloid in Alzheimer disease are antigenically related. Proc Natl Acad Sci USA 1985, 82:8729-8732.

12. Hardy JA, Higgins GA: Alzheimer's disease: the amyloid cascade hypothesis. Science 1992, 256:184-185.

13. Klein WL, Krafft GA, Finch CE: Targeting small A $\beta$ oligomers: the solution to an Alzheimer's disease conundrum? Trends Neurosci 2001, 24:219-224.

14. De Felice FG, Ferreira ST: $\beta$-Amyloid production, aggregation, and clearance as targets for therapy in Alzheimer's disease. Cell Mol Neurobiol 2002, 22:545-563.
15. Citron M: Strategies for disease modification in Alzheimer's disease. Nat Rev Neurosci 2004, 5:677-685.

16. Haas C: Initiation and propagation of neurodegeneration. Nat Med 2010 16:1201-1204

17. Broersen K, Rousseau F, Schymkowitz J: The culprit behind amyloid beta peptide related neurotoxicity in Alzheimer's disease: oligomer size or conformation. Alzheimers Res Ther 2010, 2:12.

18. Wilcox KC, Lacor RN, Pitt J, Klein WL: A $\beta$ oligomer-induced synapse degeneration in Alzheimer's disease. Cell Mol Neurobiol 2011, 31:939-948.

19. Moreth J, Kroker KS, Schwanzar D, Schnack C, von Arnim CAF, Hengerer B, Rosenbrock H, Kussmaul L: Globular and protofibrillar $A \beta$ aggregates impair neurotransmission by different mechanism. Biochem 2013, 52:1466-1476.

20. Walsh DM, Lamakin A, Benedek GB, Condron MM, Teplow DB: Amyloid $\beta$-protein fibrillogenesis: detection of a protofibrillar intermediated. J Biol Chem 1997, 272:22364-22372.

21. Fezoui Y, Hartley DM, Harper JD, Khurana R, Walsh DM, Condron MM, Selkoe DJ, Lansbury PT, Finnk AL, Teplow DB: An improved method of preparing the amyloid $\beta$-protein for fibrillogenesis and neurotoxicity experiments. Amyloid 2000, 7:166-178.

22. Lee S, Fernandez EJ, Good TA: Role of aggregation conditions in structure, stability, and toxicity of intermediates in the $A \beta$ fibril formation pathway. Protein Sci 2007, 16:723-732.

23. Paravastu AK, Qahwash I, Leapman RD, Meredith SC, Tycko R: Seeded growth of $\beta$-amyloid fibrils from Alzheimer's brain-derived fibrils produces a distinct fibril structure. Proc Natl Acad Sci USA 2009, 106:7443-7448.

24. Norlin N, Hellberg M, Filippov A, Sousa AA, Gröbner G, Leapman RD, Almqvist N, Antzutkin ON: Aggregation and fibril morphology of the Arctic mutation of Alzheimer's A $\beta$ peptide by CD, TEM, STEM and in situ AFM. J Struct Biol 2012, 180:174-189.

25. Morgado I, Fändrich M: Assembly of Alzheimer's $A \beta$ peptide into nanostructured amyloid fibrils. Curr Opin Colloid Interface Sci 2011, 16:508-514

26. Tekirian TL, Yang AY, Glabe C, Geddes JW: Toxicity of pyroglutaminated amyloid $\beta$-peptides $3(\mathrm{pE})-40$ and -42 is similar to that of $A \beta 1-40$ and -42 . J Neurochem 1999, 73:1584-1589.

27. Roher AE, Lowenson JD, Clarke S, Woods AS, Cotter RJ, Gowing E, Ball ML: $\beta$-Amyloid-(1-42) is a major component of cerebrovascular amyloid deposits: implications for the pathology of Alzheimer disease. Proc Nat/ Acad Sci USA 1993, 90:10836-10840.

28. Thal DR, Capetillo-Zarate E, Del Tredici K, Braak H: The development of amyloid beta protein deposits in the aged brain. Sci Aging Knowledge Environ 2006, 2006:re1.

29. Podlisny MB, Ostaszewski BL, Squazzo SL, Koo EH, Rydell RE, Teplow DB, Selkoe DJ: Aggregation of secreted amyloid $\beta$-protein into sodium dodecyl sulfate-stable oligomers in cell culture. J Biol Chem 1995, 270:9564-9570.

30. Walsh DM, Klyubin I, Fadeeva JV, Rowan MJ, Selkoe DJ: Amyloid- $\beta$ oligomers: their production, toxicity and therapeutic inhibition. Biochem Soc Trans 2002, 30:552-557.

31. Cleary JP, Walsh DM, Hofmeister JJ, Shankar GM, Kushowski MA, Selkoe DJ, Ashe $\mathrm{KH}$ : Natural oligomers of the amyloid- $\beta$ protein specifically disrupt cognitive function. Nat Neurosci 2005, 8:79-84.

32. Townsend M, Cleary JP, Mehta T, Hofmeister J, Lesne S, O'Hare E, Walsh DM, Selkoe DJ: Orally available compound prevents deficits in memory caused by the Alzheimer amyloid- $\beta$ oligomers. Ann Neurol 2006, 60:668-676.

33. Reed MN, Hofmeister JJ, Jungbauer L, Welzel AT, Yu C, Sherman MA, Lesné S, LaDu MJ, Walsh DM, Ashe KH, Cleary JP: Cognitive effects of cell-derived and synthetically derived A $\beta$ oligomers. Neurobiol Aging 2011, 32:1784-1794.

34. Freir DB, Fedriani R, Scully D, Smith IM, Selkoe DJ, Walsh DM, Regan CM: A oligomers inhibit synapse remodeling necessary for memory consolidation. Neurobiol Aging 2011, 32:2211-2218.

35. Shankar GM, Li S, Mehta TH, Garcia-Munoz A, Shepardson NE, Smith I, Brett FM, Farrell MA, Rowan MJ, Lemere CA, Regan CM, Walsh DM, Sabatini BL, Selkoe DJ: Amyloid- $\beta$ protein dimers isolated directly from Alzheimer's brains impair synaptic plasticity and memory. Nat Med 2008, 14:837-842.

36. Townsend M, Shankar GM, Mehta T, Walsh DM, Selkoe DJ: Effects of secreted oligomers of amyloid $\beta$-protein on hippocampal synaptic plasticity: a potent role for trimers. J Physiol 2006, 572:477-492. 
37. Lesné S, Koh MT, Kotilinek L, Kayed R, Glabe CG, Yang A, Gallagher M, Ashe KH: A specific amyloid- $\beta$ protein assembly in the brain impairs memory. Nature 2006, 440:352-357.

38. Chen $Y$-R, Clabe CG: Distinct early folding and aggregation properties of Alzheimer amyloid- $\beta$ peptides $A \beta 40$ and $A \beta 42$. J Biol Chem 2006, 281:24414-24422

39. Bitan G, Vollers SS, Teplow DB: Elucidation of primary structure elements controlling early amyloid $\beta$-protein oligomerization. J Biol Chem 2003, 278:34882-34889.

40. Barghorn S, Nimmrich V, Striebinger A, Krantz C, Keller P, Janson B, Bahr M Schmidt M, Bitner RS, Harlan J, Barlow E, Ebert U, Hillen H: Globular amyloid $\beta$-peptide ${ }_{1-42}$ oligomer - a homogenous and stable neuropathological protein in Alzheimer's disease. J Neurochem 2005, 95:834-847.

41. Larson $M E$, Lesné $S E$ : Soluble $A \beta$ oligomer production and toxicity. J Neurochem 2012, 120(Suppl 1):125-139.

42. Lambert MP, Barlow AK, Chromy BA, Edwards C, Freed R, Liosatos M, Morgan TE, Rozovsky I, Trommer B, Viola KL, Wals P, Zhang C, Finch CE, Krafft GA, Klein WL: Diffusible, non-fibrillar ligands derived from A $\beta 1-42$ are potent central nervous system neurotoxins. Proc Natl Acad Sci USA 1998, 95:6448-6453.

43. Stine WB, Dahlgren KN, Krafft GA, LaDu MJ: In vitro characterization of conditions for amyloid- $\beta$ peptide oligomerization and fibrillogenesis. J Mol Biol 2003, 278:11612-11622.

44. Hepler RW, Grimm KM, Nahas DD, Breese R, Dodson EC, Acton P, Keller PM, Yeager $M$, Wang $H$, Shughrue $P$, Kinney $G$, Joyce JG: Solution state characterization of amyloid $\beta$-derived diffusible ligands. Biochem 2006 45:15157-15167.

45. Deshpande A, Mina E, Glabe C, Busciglio J: Different conformations of amyloid $\beta$ induce neurotoxicity by distinct mechanisms in human cortical neurons. J Neurosci 2006, 26:6011-6018.

46. Kayed R, Head E, Sarsoza F, Saing T, Cotman CW, Necula M, Margol L, Wu J, Breydo L, Thompson JL, Rasool S, Gurlo T, Butler P, Glabe CG: Fibril specific, conformation depended antibodies recognize a generic epitope common to amyloid fibrils and fibrillar oligomers that is absent in prefibrillar oligomers. Mol Neurodegen 2007, 2:18.

47. Rangachari V, Moore BD, Reed DK, Sonoda LK, Bridges AW, Conboy E, Hartigan D, Rosenberry TL: Amyloid- $\beta(1-42)$ rapidly forms protofibrils and oligomers by distinct pathways in low concentrations of sodium dodecylsulfate. Biochem 2007, 46:12451-12462.

48. Gellermann GP, Byrnes $H$, Striebinger A, Ullrich K, Mueller R, Hillen $H_{\text {, }}$ Barghorn S: A $\beta$-globulomers are formed independently of the fibril pathway. Neurobiol Dis 2008, 30:212-220.

49. Nimmrich V, Grimm C, Draguhn A, Barghorn S, Lehmann A, Schoemaker $H$, Hillen $\mathrm{H}$, Gross $\mathrm{G}$, Ebert $U$, Bruehl $C$ : Amyloid $\beta$ oligomers (A $\beta 1-42$ globulomer) suppress spontaneous synaptic activity by inhibition of P/Q-type calcium currents. J Neurosci 2008, 28:788-797.

50. Demuro A, Mina E, Kayed R, Milton SC, Parker I, Glabe CG: Calcium dysregulation and membrane disruption as a ubiquitous neurotoxic mechanism of soluble amyloid oligomers. J Biol Chem 2005, 280:17294-17300.

51. Hoshi M, Sato M, Matsumoto S, Noguchi A, Yasutake K, Yoshida N, Sato K: Spherical aggregates of $\beta$-amyloid (amylospheroid) show high neurotoxicity and activate tau protein kinase I/glycogen synthase kinase-3ß. Proc Natl Acad Sci USA 2003, 100:6370-6575.

52. Noguchi A, Matsumura S, Dezawa M, Tada M, Yanazawa M, Ito A, Akioka M, Kikuchi S, Sato M, Ideno S, Noda M, Fukunari A, Muramatsu S-i, Itokazu Y, Sato K, Takahashi H, Teplow DB, Nabeshima Y-i, Kakita A, Imahori K, Hoshi M: Isolation and characterization of patient-derived, toxic, high mass amyloid $\beta$-protein (A $\beta$ ) assembly from Alzheimer disease brains. J Biol Chem 2009, 284:32895-32905.

53. Walsh DM, Hartley DM, Kusumoto Y, Fezoui Y, Condron MM, Lomakin AL, Benedek GB, Selkoe DJ, Teplow DB: Amyloid $\beta$-protein fibrillogenesis: structure and biological activity of protofibrillar intermediates. $J$ Biol Chem 1999, 274:25945-25952.

54. Harper JD, Wong SS, Lieber CM, Lansbury PT Jr: Assembly of A $\beta$ amyloid protofibrils: an in vitro model for a possible early event in Alzheimer's disease. Biochem 1999, 38:8972-8980.

55. Lashuel HA, Hartley DM, Petre BM, Wall JS, Simon MN, Walz T, Lansbury PT: Mixtures of wild-type and a pathogenic (E22G) form of $A \beta 40$ in vitro accumulate protofibrils, including amyloid pores. J Mol Biol 2003, 332:795-808.
56. Lasagna-Reeves CA, Glabe CG, Kayed R: Amyloid- $\beta$ annular protofibrils evade fibrillar fate in Alzheimer disease brain. J Biol Chem 2011, 286:22122-22130.

57. Mehta PD, Pirttilä T, Mehta SP, Sersen EA, Aisen PS, Wisniewski HM: Plasma and cerebrospinal fluid levels of amyloid $\beta$ proteins 1-40 and 1-42 in Alzheimer disease. Arch Neurol 2000, 57:100-105.

58. Delacourte A, Sergeant N, Champain D, Wattez A, Maurage C-A, Lebert F, Pasquier F, David J-P: Nonoverlapping but synergetic tau and APP pathologies in sporadic Alzheimer's disease. Neurology 2002, 59:398-407.

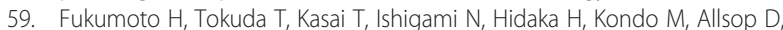
Nakagawa M: High-molecular-weight $\beta$-amyloid oligomers are elevated in cerebrospinal fluid of Alzheimer patients. FASEB J 2010, 24:2716-2726.

60. Karran E, Mercken M, De Stropper B: The amyloid cascade hypothesis for Alzheimer's disease: an appraisal for the development of therapeutics. Nat Rev Drug Disc 2011, 10:698-712.

61. Wolfe A, McCampbell A, Hatcher N, Tugusheva K, Haugabook S, Maxwell J, Wu G, Howell B, Renger J, Shughrue P, Savage M: A quantitative assay selective for amyloid oligomer species differentiates cerebrospinal fluid from Alzheimer's disease and age-matched normal. Alzheimers Dementia 2012, 8(Supplement):P278.

62. Hölttä M, Hansson O, Andreasson U, Hertze J, Minthon L, Nägga K Andreasen $N$, Zetterberg $H$, Blennow K: Evaluating amyloid- $\beta$ oligomers in cerebrospinal fluid as a biomarker for Alzheimer's disease. PLOS One 2013, 8:e66381.

63. Lue L-F, Kuo Y-M, Roher AE, Brachova L, Shen Y, Sue L, Beach T, Kurth JH, Rydel RE, Rogers J: Soluble amyloid $\beta$ peptide concentration as a predictor of synaptic change in Alzheimer's disease. Am J Pathol 1999, 155:853-862

64. McDonald JM, Cairns NJ, Taylor-Reinwald L, Holtzman D, Walsh DM: The levels of water-soluble and triton-soluble $A \beta$ are increased in Alzheimer's disease brain. Brain Res 2012, 1450:138-147.

65. Savage MJ, Kalinina J, Wolfe A, Tugusheva K, Korn R, Cash-Mason T, Maxwell JW, Hatcher NG, Haugabook SJ, Wu G, Howell BJ, Renger JJ, Shughrue PJ, McCampbell A: A sensitive A $\beta$ oligomer assay discriminates Alzheimer's and aged control cerebrospinal fluid. J Neurosci 2014, 34:2884-2897.

66. Johnson RD, Schauerte JA, Wisser KC, Gafni A, Steel DG: Direct observation of single amyloid- $\beta(1-40)$ oligomers on live cells: binding and growth at physiological concentrations. PLoS One 2011, 6:e23970.

67. Johnson RD, Schauerte JA, Chang C-C, Wisser KC, Althaus JC, Carruthers CJL, Sutton MA, Steel DG, Gafni A: Single-molecule imaging reveals $A \beta 42: A \beta 40$ ratio-dependent oligomer growth on neuronal processes. Biophys J 2013, 104:894-903.

68. Lansbury PT: Evolution of amyloid: what normal protein folding may tell us about fibrillogenesis and disease. Proc Natl Acad Sci USA 1999, 96:3342-3344

69. Serpell LC: Alzheimer's amyloid fibrils: structure and assembly. Biochim Biophys Acta 2000, 1502:16-30.

70. Blackley HK, Sanders GH, Davies MC, Roberts CJ, Tendler SJ, Wilkinson MJ: In-situ atomic force microscopy study of $\beta$-amyloid fibrillization. J Mol Biol 2000, 298:833-840

71. Kirkitadze MD, Condron MM, Teplow DB: Identification and characterization of key kinetic intermediates in amyloid $\beta$-protein fibrillogenesis. $\mathrm{J}$ Mol Biol 2001, 312:1103-1119.

72. Caughey B, Lansbury PT: Protofibrils, pores, fibrils, and neurodegeneration: separating the responsible protein aggregates from the innocent bystanders. Annu Rev Neurosci 2003, 26:267-298.

73. Cohen SI, Linse S, Luheshi LM, Hellstrand E, White DA, Rajah L, Otzen DE, Vendruscolo M, Dobson CM, Knowles TP: Proliferation of amyloid- $\beta 42$ aggregates occurs through a secondary nucleation mechanism. Proc Natl Acad Sci USA 2013, 110:9758-9763.

74. Jeong JS, Ansaloni A, Mezzenga R, Lashuel HA, Dietler G: Novel mechanistic insight into the molecular basis of amyloid polymorphism and secondary nucleation during amyloid formation. J Mol Biol 2013, 425:1765-1781.

75. Stefani M: Biochemical and biophysical features of both oligomer/ fibril and cell membrane in amyloid cytotoxicity. FEBS J 2010, 277:4602-4613.

76. Lanz TA, Himes CS, Pallante G, Adams L, Yamazaki S, Amore B, Merchant KM: The $\gamma$-secretase inhibitor $\mathrm{N}$-[N-(3,5-difluorophenacetyl)-L-alanyl]-Sphenylglycine t-butyl ester reduces $A \beta$ levels in vivo in plasma and cerebrospinal fluid in young (plaque-free) and aged (plaque-bearing) Tg2576 mice. J Pharmacol Exp Ther 2003, 305:864-871. 
77. Barten DM, Guss VL, Corsa JA, Loo A, Hansel SB, Zheng M, Munoz B, Srinivasan $\mathrm{K}$, Wang B, Robertson BJ, Polson CT, Wang J, Roberts SB, Hendrick JP, Anderson JJ, Loy JK, Denton R, Verdoorn TA, Smith DW, Felsenstein KM: Dynamics of $\beta$-amyloid reductions in brain, cerebrospinal fluid, and plasma of $\beta$-amyloid precursor protein transgenic mice treated with a -secretase inhibitor. J Pharmacol Exp Ther 2005, 312:635-643.

78. Abramowski D, Wiederhold K-H, Furrer U, Jaton A-L, Neuenschwander A, Runser M-J, Danner S, Reichwald J, Ammaturo D, Staab D, Stoeckli M, Rueeger $H$, Neumann $U$, Staufenbiel M: Dynamics of $A \beta$ turnover and deposition in different $\beta$-amyloid precursor protein transgenic mouse models following $\gamma$-secretase inhibition. J Pharmacol Exp Ther 2008, 327:411-424.

79. Garcia-Alloza M, Subramanian M, Thyssen D, Borrelli LA, Fauq A, Das P, Golde TE, Hyman BT, Bacskai BJ: Existing plaques and neuritic abnormalities in APP:PS1 mice are not affected by administration of the gamma-secretase inhibitor LY-411575. Mol Neurodegen 2009, 4:19.

80. Jankowsky JL, Slunt HH, Gonzales V, Savonenko AV, Wen JC, Jenkins NA, Copeland NG, Younkin LH, Lester HA, Younkin SG, Borchelt DR: Persistent amyloidosis following suppression of $A \beta$ production in a transgenic model of Alzheimer disease. PLOS Med 2005, 2:e355.

81. Melnikova T, Fromholt S, Kim HS, Lee D, Xu G, Price A, Moore BD, Golde TE, Felsenstein KM, Savonenko A, Borchelt DR: Reversible pathologic and cognitive phenotypes in an inducible model of Alzheimer-amyloidosis. J Neurosci 2013, 33:3765-3779.

82. Das P, Murphy MP, Younkin LA, Younkin SG, Golde TE: Reduced effectiveness of A 1-42 immunization in APP transgenic mice with significant amyloid deposition. Neurobiol Aging 2001, 22:721-727.

83. Cheng IH, Scearce-Levie K, Legleiter J, Palop JJ, Gerstein H, Bien-Ly N, Puoliväli J, Lesné S, Ashe KH, Muchowski PJ, Mucke L: Accelerating amyloid- $\beta$ fibrillization reduces oligomer levels and functional deficits in Alzheimer disease mouse models. J Biol Chem 2007, 282:23818-23828.

84. Lesné $S$, Kotilinek $L$, Ashe $\mathrm{KH}$ : Plaque-bearing mice with reduced levels of oligomeric amyloid- $\beta$ assemblies have intact memory function. Neurosci 2008, 151:745-749.

85. Cirrito JR, May PC, O'Dell MA, Taylor JW, Parsadanian M, Cramer JW, Audia JE, Nissen JS, Bales KR, Paul SM, DeMattos RB, Holtzman DM: In vivo assessment of brain interstitial fluid with microdialysis reveals plaque-associated changes in amyloid- $\beta$ metabolism and half-life. J Neurosci 2003, 23:8844-8853.

86. Hong S, Quintero-Monzon O, Ostaszewski BL, Podlisny DR, Cavanaugh WT, Yang T, Holtzman DM, Cirrito JR, Selkoe DJ: Dynamic analysis of amyloid $\beta$-protein in behaving mice reveals opposing changes in ISF vs. parenchymal $A \beta$ during age-related plaque formation. J Neurosci 2011, 31:15861-15869.

87. Takeda S, Hashimoto T, Roe AD, Hori Y, Spires-Jones TL, Hyman BT: Brain interstitial oligomeric amyloid $\beta$ increases with age and is resistant to clearance from brain in a mouse model of Alzheimer's disease. FASEB J 2013, 27:3239-3248

88. Narayan P, Ganzinger KA, McColl J, Weimann L, Meehan S, Qamar S, Carver JA, Wilson MR, St George-Hyslop P, Dobson CM, Klenerman D: Single molecule characterization of the interactions between amyloid- $\beta$ peptides and the membranes of hippocampal cells. J Am Chem Soc 2013, 135:1491-1498.

89. Gravina SA, Ho L, Eckman CB, Long KE, Otvos L, Younkin LH, Suzuki N, Younkin SG: Amyloid $\beta$ protein $(A \beta)$ in Alzheimer's disease brain: biochemical and immunocytochemical analysis with antibodies specific for forms ending at $A \beta 40$ or $A \beta 42(43)$. J Biol Chem 1995, 270:7013-1016.

90. Wetzel R: Kinetics and thermodynamics of amyloid fibril assembly. Acc Chem Res 2006, 39:671-679.

91. Sánchez L, Madurga S, Pukala T, Vilaseca M, López-lglesias C, Robinson CV, Giralt E, Carulla N: $A \beta 40$ and $A \beta 42$ amyloid fibrils exhibit distinct molecular recycling properties. J Am Chem Soc 2011, 133:6505-6508.

92. Esler WP, Stimson ER, Jennings JM, Vinters HV, Ghilardi JR, Lee JP, Mantyh PW, Maggio JE: Alzheimer's disease amyloid propagation by a templatedependent dock-lock mechanism. Biochem 2000, 39:6288-6295.

93. Koffie RM, Mayer-Luehmann M, Hashimoto T, Adams KW, Mielke ML, Garcia-Alloza M, Micheva KD, Smith SJ, Kim ML, Lee VM, Hyman BT, Spires-Jones TL: Oligomeric amyloid $\beta$ associates with postsynaptic densities and correlates with excitatory synapse loss near senile plaques. Proc Natl Acad Sci USA 2009, 106:4012-4017.
94. Atwood CA, Obrenovich ME, Liu T, Chan H, Perry G, Smith MA, Martins RN: Amyloid- $\beta$ : a chameleon walking in two worlds: a review of the trophic and toxic properties of amyloid- $\beta$. Brain Res Rev 2003, 43:1-16.

95. Giuffrida ML, Caraci F, Pagnataro B, Cataldo S, De Bona P, Bruno V, Molinaro G, Pappalardo G, Messina A, Palmigiano A, Garozzo D, Nicoletti F, Rizzarelli E, Copani A: $\beta$-Amyloid monomers are neuroprotective. J Neurosci 2009, 29:10582-10587.

96. Baglioni S, Casamenti F, Bucciantini M, Luheshi LM, Taddei N, Chiti F, Dobson CM, Stefani M: Prefibrillar amyloid aggregates could be generic toxins in higher organisms. J Neurosci 2006, 26:8160-8162.

97. Treusch S, Cyr DM, Lindquist S: Amyloid deposits: protection against toxic protein species? Cell Cycle 2009, 8:1668-1674.

98. Oda T, Wals P, Osterburg HH, Johnson SA, Pasinetti GM, Morgan TE, Rozovsky I, Stine WB, Snyder SW, Holzman TF, Krafft GA, Finch CE: Clusterin (apoJ) alters the aggregation of amyloid $\beta$-peptide (A $\beta 1-42)$ and forms slowly sedimenting $A \beta$ complexes that cause oxidative stress. Exp Neurobiol 1995, 136:22-31.

99. Standridge JB: Vicious cycles within the neuropathophysiologic mechanisms of Alzheimer's disease. Curr Alzheimers Res 2006, 3:95-107.

100. Zemple $H$, Thies E, Mandelkow E, Mandelkow EM: Abeta oligomers cause localized $\mathrm{Ca}^{2+}$ elevation, missorting of endogenous Tau into dendrites, Tau phosphorylation, and destruction of microtubules and spines. J Neurosci 2010, 30:11938-11950.

101. Klyubin I, Cullen WK, Hu N-W, Rowan MJ: Alzheimer's disease $A \beta$ assemblies mediating rapid disruption of synaptic plasticity and memory. Molecular Brain 2012, 5:25.

102. Kittelberger KA, Piazza F, Tesco G, Reijmers LG: Natural amyloid-beta oligomers acutely impair the formation of a contextual fear memory in mice. PLoS One 2012, 7:e29940.

103. Puzzo D, Privitera L, Leznik E, Fà M, Staniszewski A, Palmeri A, Arancio O: Picomolar amyloid- $\beta$ positively modulates synaptic plasticity and memory in hippocampus. J Neurosci 2008, 28:14537-14545.

104. Puzzo D, Privitera L, Fà M, Staniszewski A, Hashimoto G, Aziz F, Sakurai M, Ribe EM, Troy CM, Merchen M, Jung SS, Palmeri A, Arancio O: Endogenous amyloid- $\beta$ is necessary for hippocampal synaptic plasticity and memory. Ann Neurol 2011, 69:819-830.

105. Puzzo D, Arancio O: Amyloid- $\beta$ peptide: Dr. Jekyll or Mr. Hyde? J Alzheimers Dis 2013, 33:S111-S120

106. Lacor PN, Buniel MC, Chang L, Fernandez SJ, Gong Y, Viola KL, Lambert MP, Velasco PT, Bigio EH, Finch CE, Krafft GA, Klein WL: Synaptic targeting by Alzheimer's-related amyloid $\beta$ oligomers. J Neurosci 2004, 24:10191-10200.

107. Lacor PN, Buniel MC, Furlow PW, Clemente AS, Velasco PT, Wood M, Viola KL, Klein WL: $A \beta$ oligomer-induced aberrations in synapse composition, shape, and density provide a molecular basis for loss of connectivity in Alzheimer's disease. J Neurosci 2007, 27:796-807.

108. Shughrue PJ, Acton PJ, Breese RS, Zhao W-Q, Chen-Dodson E, Hepler RW, Wolfe AL, Matthews M, Heidecker GJ, Joyce JG, Villarreal SA, Kinney JJ: Anti-ADDL antibodies differentially block oligomer binding to hippocampal neurons. Neurobiol Aging 2010, 31:189-202.

109. Rammes G, Hasenjager A, Sroka-Saidi K, Deussing JM, Parsons CG: Therapeutic significance of NR2B-containing NMDA receptors and mGluR5 metabotropic glutamate receptors in mediating the synaptotoxic effects of $\beta$-amyloid oligomers on long-term potentiation (LTP) in murine hippocampal slices. Neuropharmacology 2011, 60:982-990.

110. Poling A, Paisley-Morgan K, Panos JJ, Kim E-M, O'Hare E, Cleary JP, Lesné S, Ashe $\mathrm{KH}$, Porritt M, Baker L: Oligomers of the amyloid-beta protein disrupt working memory: confirmation with two behavioral procedures. Behav Brain Res 2008, 193:230-234.

111. De Felice FG, Wu D, Lambert MP, Fernandez SJ, Velasco PT, Lacor PN, Bigio EH, Jerecic J, Acton PJ, Shughrue PJ, Chen-Dodson E, Kinney GG, Klein WL: Alzheimer's disease-type neuronal tau hyperphosphorylation induced by A $\beta$ oligomers. Neurobiol Aging 2008, 29:1334-1347.

112. Jin M, Shepardson N, Yang T, Chen G, Walsh D, Selkoe DJ: Soluble amyloid $\beta$-protein dimers isolated from Alzheimer cortex directly induce Tau hyperphosphorylation and neuritic degeneration. Proc Natl Acad Sci USA 2011, 108:5819-5824.

113. Chabrier MA, Blurton-Jones M, Agazaryan AA, Nerhus JL, Martinez-Coria $H$, LaFerla FM: Soluble $A \beta$ promotes wild-type tau pathology in vivo. J Neurosci 2012, 32:17345-17350.

114. Oddo S, Caccamo A, Tran L, Lambert MP, Glabe CG, Klein WL, LaFerla FM: Temporal profile of amyloid- $\beta$ ( $A \beta$ ) oligomerization in an in vivo model 
of Alzheimer disease: a link between $A \beta$ and tau pathology. $J$ Biol Chem 2006, 281:1599-1604.

115. Small SA, Duff K: Linking $A \beta$ and tau in late-onset Alzheimer's disease: a dual pathway hypothesis. Neuron 2008, 60:534-542.

116. Zempel H, Luedtke J, Kumar Y, Biernat J, Dawson H, Mandelkow E, Kandelkow E-M: Amyloid- $\beta$ oligomers induce synaptic damage via Tau-dependent microtubule severing by TTLL6 and spastin. EMBO J 2013, 32:2920-2937

117. Kuo YM, Emmerling MR, Vigo-Pelfrey C, Kasunic TC, Kirkpatrick JB, Murdoch GH, Ball MJ, Roher AE: Water-soluble $\mathrm{A} \beta(\mathrm{N}-40, \mathrm{~N}-42)$ oligomers in normal and Alzheimer's disease brains. J Biol Chem 1996, 271:4077-4081.

118. Gong Y, Chang L, Viola KL, Lacor PN, Lambert MP, Finch CE, Krafft GA, Klein WL: Alzheimer's disease-affected brain: presence of oligomeric $A \beta$ ligands (ADDLs) suggests a molecular basis for reversible memory loss. Proc Natl Acad Sci USA 2003, 100:10417-10422.

119. Sehlin D, Englund H, Simu B, Karlsson M, Ingelsson M, Nikolajeff F, Lannfelt L, Pettersson FE: Large aggregates are the major soluble $A \beta$ species in $A D$ brain fractionated with density gradient ultracentrifugation. PLOS One 2012, 7:e32014.

120. Georganopoulou DG, Chang L, Nam J-M, Thaxton SC, Mufson EJ, Klein WL, Mirkin CA: Nanoparticle-based detection in cerebral spinal fluid of a soluble pathogenic biomarker for Alzheimer's disease. Proc Natl Acad Sci USA 2005, 102:2273-2276.

121. Gao CM, Yam AY, Wang X, Magdangal E, Salisbury C, Peretz D, Zuckermann RN, Connolly MD, Hansson O, Minthon L, Zetterberg H, Blennow K, Fedynyshyn JP, Allauzen S: A 40 oligomers identified as a potential biomarker for the diagnosis of Alzheimer's disease. PLoS One 2010, 5:e15725.

122. Santos AN, Ewers M, Minthon L, Simm A, Silber R-E, Blennow K, Prvulovic D, Hansson $\mathrm{O}$, Hampel $\mathrm{H}$ : Amyloid- $\beta$ oligomers in cerebrospinal fluid are associated with cognitive decline in patients with Alzheimer's disease. J Alzheimer's Dis 2012, 29:171-176.

123. Esparza TJ, Zhao H, Cirrito JR, Cairns NJ, Bateman RJ, Holtzman DM, Brody DL: Amyloid-beta oligomerization in Alzheimer dementia versus high-pathology controls. Ann Neurol 2013, 73:104-119.

124. Herskovits AZ, Locascio JJ, Peskind ER, Li G, Hyman BT: A luminex assay detects amyloid $\beta$ oligomers in Alzheimer's disease cerebrospinal fluid. PLoS One 2013, 8:e67898.

125. Glabe CG: Structural classification of toxic amyloid oligomers. J Biol Chem 2008, 283:29639-29643.

126. Rahimi F, Shanmugam A, Bitan G: Structure-function relationships of pre-fibrillar protein assemblies in Alzheimer's disease and related disorders. Curr Alzheimer Res 2008, 5:319-341.

127. Fändrich M: Oligomeric intermediates in amyloid formation: structure determination and mechanisms of toxicity. J Mol Biol 2012, 421:427-440

128. Roher AE, Chaney MO, Kuo Y-M, Webster SD, Stine WB, Haverkamp L, Woods AS, Cotter RJ, Tuohy JM, Krafft GA, Bonnell BS, Emmerling MR: Morphology and toxicity of $A \beta-(1-42)$ dimer derived from neuritic and vascular amyloid deposits of Alzheimer's disease. J Biol Chem 1996, 271:20631-20635.

129. Hu N-W, Smith IM, Walsh DM, Rowan MJ: Soluble amyloid- $\beta$ peptides potently disrupt hippocampal synaptic plasticity in the absence of cerebrovascular dysfunction in vivo. Brain 2008, 131:2414-2424.

130. Hartley DM, Walsh DM, Ye CP, Diehl T, Vasquez S, Vassilev PM, Teplow DB, Selkoe DJ: Protofibrillar intermediates of amyloid $\beta$-protein induce acute electrophysiological changes and progressive neurotoxicity in cortical neurons. J Neurosci 1999, 19:8876-8884.

131. Peng S, Garzon DJ, Marchese M, Klein W, Ginsberg SD, Francis BM, Mount HT, Mufson EJ, Salehi A, Fahnestock M: Decreased brain-derived neurotrophic factor depends on amyloid aggregation state in transgenic mouse models of Alzheimer's disease. J Neurosci 2009, 29:9321-9329.

132. Chromy BA, Nowak RJ, Lambert MP, Viola KL, Chang L, Velasco PT, Jones BW, Fernandez SJ, Lacor PN, Horowitz P, Finch CE, Krafft GA, Klein WL: Self-assembly of A A1-42 into globular neurotoxins. Biochem 2003, 42:12749-12760.

133. Ono K, Condron MM, Teplow DB: Structure-neurotoxicity relationships of amyloid $\beta$-protein oligomers. Proc Natl Acad Sci USA 2009, 106:14745-14750

134. Rönicke R, Klemm A, Meinhardt J, Schröder UH, Fändrich M, Reymann KG: $A \beta$ mediated diminution of MMT reduction - an artefact of single cell culture? PLoS One 2008, 3:e3236.

135. Podlisny MB, Walsh DM, Amarante P, Ostaszewski BL, Stimson ER, Maggio JE, Teplow DB, Selkoe DJ: Oligomerization of endogenous and synthetic amyloid $\beta$-protein at nanomolar levels in cell culture and stabilization of monomer by Congo red. Biochemistry 1998, 37:3602-3611.

136. Walsh DM, Klyubin I, Fadeeva JV, Cullen WK, Anwyl R, Wolfe MS, Rowan MJ, Selkoe DJ: Naturally secreted oligomers of amyloid $\beta$ protein potently inhibit hippocampal long-term potentiation in vivo. Nature 2002, 416:535-539.

137. Walsh DM, Townsend M, Podlisny MB, Shankar GM, Fadeeva JV, Agnaf OE, Hartley DM, Selkoe DJ: Certain inhibitors of synthetic amyloid $\beta$-peptide $(A B)$ fibrillogenesis block oligomerization of natural $A \beta$ and thereby rescue long-term potentiation. J Neurosci 2005, 25:2455-2462.

138. Bitan G, Fradinger EA, Spring SM, Teplow DB: Neurotoxic protein oligomers - what you see is not always what you get. Amyloid 2005, 12:88-95.

139. Kimura R, MacTavish D, Yang J, Westaway D, Jhamandas JH: Beta amyloid-induced depression of hippocampal long-term potentiation is mediated through the amylin receptor. J Neurosci 2012, 32:17401-17406

140. Shankar GM, Bloodgood BL, Townsend M, Walsh DM, Selkoe DJ, Sabatini BL: Natural oligomers of the Alzheimer amyloid- $\beta$ protein induce reversible synapse loss by modulating an NMDA-type glutamate receptor-dependent signaling pathway. J Neurosci 2007, 27:2866-2875.

141. Li S, Hong S, Shepardson NE, Walsh DM, Shankar GM, Selkoe D: Soluble oligomers of amyloid $\beta$ protein facilitate hippocampal long-term depression by disrupting neuronal glutamate uptake. Neuron 2009, 62:788-801.

142. Wei W, Nguyen LN, Kessels HW, Hagiwara H, Sisodia S, Malinow R: Amyloid beta from axons and dendrites reduces local spine number and plasticity. Nat Neurosci 2010, 13:190-196.

143. Tamburri A, Dudilot A, Licea S, Bourgeois C, Boehm J: NMDA-receptor activation but not ion flux is required for amyloid-beta induced synaptic depression. PLoS One 2013, 8:e65350.

144. Malinow R: New developments on the role of NMDA receptors in Alzheimer's disease. Curr Opin Neurobiol 2012, 22:559-563.

145. Takamura A, Sato Y, Watabe D, Okamoto Y, Nakata T, Kawarabayashi T, Oddo S, Laferla FM, Shoji M, Matsubara E: Sortilin is required for toxic action of $A \beta$ oligomers ( $A \beta O s)$ : extracellular $A \beta O$ s trigger apoptosis, and intraneuronal ABOs impair degradation pathways. Life Sci 2012, 91:1177-1186.

146. Zhang Y, McLaughlin R, Goodyer C, LeBlanc A: Selective cytotoxicity of intracellular amyloid $\beta$ peptide ${ }_{1-42}$ through $\mathrm{p} 53$ and Bax in cultured primary human neurons. J Cell Biol 2002, 156:519-529.

147. Vitolo OV, Sant'Angelo A, Costanzo V, Battaglia F, Arancio O, Shelanski M: Amyloid $\beta$-peptide inhibition of the PKA/CREB pathway and long-term potentiation: reversibility by drugs that enhance CAMP signaling. Proc Natl Acad Sci USA 2002, 99:13217-13221.

148. Smith DL, Pozueta J, Gong B, Arancio O, Shelanski M: Reversal of long-term dendritic spine alterations in Alzheimer disease models. Proc Natl Acad Sci USA 2009, 106:16877-16882

149. Wang Q, Walsh DM, Rowan MJ, Selkoe DJ, Anwyl R: Block of long-term potentiation by naturally secreted and synthetic amyloid $\beta$-peptide in hippocampal slices is mediated via activation of the kinases c-Jun $\mathrm{N}$-terminal kinase, cyclin-dependent kinase 5 , and p38 mitogen-activated protein kinase as well as metabotropic glutamate receptor type 5 . J Neurosci 2004, 24:3370-3378.

150. Tsigelny IF, Crews L, Desplats P, Shaked GM, Sharikov Y, Mizuno H, Spencer B, Rockenstein E, Trejo M, Platoshyn O, Yuan JX-J, Masliah E: Mechanisms of hybrid oligomer formation in the pathogenesis of combined Alzheimer's and Parkinson's diseases. PLoS One 2008, 3:e3135.

151. Cisse M, Halabisky B, Harris J, Devidze N, Dubal DB, Sun B, Orr A, Lotz G, Kim DH, Hamto P, Ho K, Yu G-Q, Mucke L: Reversing EphB2 depletion rescues cognitive functions in Alzheimer model. Nature 2011, 469:47-52.

152. Yu C, Nwabuisi-Heath E, Laxton K, LaDu MJ: Endocytic pathways mediating oligomeric Aß42 neurotoxicity. Mol Neurodegener 2010, 5:19.

153. Renner M, Lacor PN, Velasco PT, Xu J, Contractor A, Klein WL, Triller A: Deleterious effects of amyloid $\beta$ oligomers acting as an extracellular scaffold for mGluR5. Neuron 2010, 66:739-754.

154. Um JW, Kaufman AC, Kostylev M, Heiss JK, Stagi M, Takahashi H, Kerrisk ME, Vortmeyer A, Wisniewski T, Koleske AJ, Gunther EC, Nygaard HB, Strittmatter SM: Metabotropic glutamate receptor 5 is a coreceptor for Alzheimer $A \beta$ oligomer bound to cellular prion protein. Neuron 2013, 79:887-902. 
155. Paranjape GS, Gouwens LK, Osborn DC, Nishols MR: Isolated amyloid(1-42) protofibrils, but not isolated fibrils, are robust stimulators of microglia. ACS Chem Neurosci 2012, 3:302-311.

156. Ostapchenko VG, Beraldo FH, Mohammad AH, Xie Y-F, Hirata PHF, Magalhaes AC, Lamour G, Li H, Maciejewski A, Belrose JC, Teixeira BL, Fahnestock M, Ferreira ST, Cashman NR, Hajj GNM, Jackson MF, Choy W-Y, MacDonald JF, Martins VR, Prado VF, Prado MAM: The prion protein ligand, stress-inducible phosphoprotein 1, regulates amyloid- $\beta$ oligomer toxicity. J Neurosci 2013, 33:16552-16564.

157. Younan ND, Sarell CJ, Davies P, Brown DR, Viles JH: The cellular prion protein traps Alzheimer's $A \beta$ in an oligomeric form and disassembles amyloid fibers. FASEB J 2013, 27:1847-1858.

158. Um JW, Nygaard HB, Heiss JK, Kostylev MA, Stagi M, Vortmeyer A, Wisniewski T, Gunther EC, Strittmatter SM: Alzheimer amyloid- $\beta$ oligomer bound to post-synaptic prion protein activates Fyn to impair neurons. Nat Neurosci 2012, 15:1227-1235.

159. Larson M, Sherman MA, Amar F, Nuvolone M, Schneider JA, Bennett DA, Aguzzi A, Lesné SE: The complex PrPC-Fyn couples human oligomeric $A \beta$ with pathological tau changes in Alzheimer's disease. J Neurosci 2012, 32:16857-16871.

160. Zhao W-Q, Santini F, Breese R, Ross D, Zhang XD, Stone DJ, Ferrer M, Townsend M, Wolfe AL, Seager MA, Kinney GG, Shughrue PJ, Ray WJ: Inhibition of calcineurin-mediated endocytosis and a-amino-3hydroxy-5-methyl-4-isoxazoleproprionic acid (AMPA) receptors prevents amyloid $\beta$ oligomer-induced synaptic disruption. J Biol Chem 2010, 285:7619-7632.

161. Wu H-Y, Hudry E, Hashimoto T, Kuchibhotla K, Rozkalne A, Fan Z, SpiresJones T, Xie H, Arbel-Ornath M, Grosskreutz CL, Bacskai BJ, Hyman BT Amyloid $\beta$ induces the morphological neurodegenerative triad of spine loss, dendritic simplification, and neuritic dystrophies through calcineurin activation. J Neurosci 2010, 30:2636-2649.

162. Wu H-Y, Hudry E, Hashimoto T, Uemura K, Fan Z-Y, Berezovska O, Grosskreutz CL, Bacskai BJ, Hyman BT: Distinct dendritic spine and nuclear phases of calcineurin activation after exposure to amyloid- $\beta$ revealed by a novel fluorescence resonance energy transfer assay. J Neurosci 2012, 32:5298-5309.

163. Kim T, Vidal GS, Djurisic M, William CM, Birnbaum ME, Garcia KC, Hyman BT, Shatz CJ: Human LilrB2 is a $\beta$-amyloid receptor and its murine homolog PirB regulates synaptic plasticity in an Alzheimer's model. Science 2013, 341:1399-1404.

164. Townsend M, Mehta T, Selkoe DJ: Soluble A $\beta$ inhibits specific signal transduction cascades common to the insulin receptor pathway. J Biol Chem 2007, 282:33305-33312.

165. Catalano SM, Rishton G, Izzo NJ: Compositions and methods for treating neurodegenerative disease, International Patent Publication Number, WO 2013/029060 A2. 2013.

166. Benilova I, De Strooper B: Promiscuous Alzheimer's amyloid: yet another partner. Science 2013, 341:1354-1355.

167. Teblow DB: On the subject of rigor in the study of amyloid $\beta$-protein assembly. Alzheimers Res Ther 2013, 5:39.

168. Stine WB, Jungbauer $L, Y u C$, LaDu MJ: Preparing synthetic $A \beta$ in different aggregation states. Methods Mol Biol 2011, 670:13-32.

169. Ryan DA, Narrow WC, Federoff HJ, Bowers WJ: An improved method of generating consistent soluble amyloid-beta oligomer preparations for in vitro neurotoxicity studies. J Neurosci Methods 2010, 190:171-179.

170. Zago W, Buttini M, Comery TA, Nishioka C, Gardai SJ, Seubert P, Games D, Bard F, Schenk D, Kinney GG: Neutralization of soluble, synaptotoxic amyloid $\beta$ species by antibodies is epitope specific. J Neurosci 2012, 32:2696-2702.

171. Yu YJ, Watts RJ: Developing therapeutic antibodies for neurodegenerative disease. Neurotherapeutics 2013, 10:459-472.

172. Ahmed M, Davis J, Aucoin D, Sato T, Ahuja S, Aimoto S, Elliott Jl, Van Nostrand WE, Smith SO: Structural conversion of neurotoxic amyloid- $\beta$ (1-42) oligomers to fibrils. Nat Struct Mol Biol 2010, 17:561-567.

173. Chaney MO, Webster SD, Kuo YM, Foher AF: Molecular modeling of the A 1 1-42 peptide from Alzheimer's disease. Protein Eng 1998, 11:761-767.

174. Mastrangelo IA, Ahmed M, Sato T, Liu W, Wang C, Hough P, Smith SO: High-resolution atomic force microscopy of soluble $A \beta 42$ oligomers. J Mol Biol 2006, 358:106-119.
175. Cerf E, Sarroukh R, Tamamizu-Kato S, Breydo L, Derclaye S, Dufrêne YF, Narayanaswami V, Goormaghtigh E, Ruysschaert J-M, Raussens V: Antiparallel $\beta$-sheet: a signature structure of the oligomeric amyloid B-peptide. Biochem J 2009, 421:415-423.

176. Hillen H, Barghorn S, Striebinger A, Labkovsky B, Müller R, Nimmrich V, Nolte MW, Perez-Cruz C, van der Auwera I, van Leuven F, van Gaalen M, Bespalov AY, Schoemaker H, Sullivan JP, Ebert U: Generation and therapeutic efficacy of highly oligomer-specific $\beta$-amyloid antibodies. J Neurosci 2010, 30:10369-10379.

177. Krafft GA, Hefti F, Goure WF, Jerecic J, Iverson KS, Walicke P, Dodart J-C: ACU-193: a drug candidate antibody that selectively targets soluble $A \beta$ oligomers. Alzheimers Dement 2013, 9:P326.

178. Salloway S, Sperling R, Gilman S, Fox NC, Blennow K, Raskind M, Sabbagh M, Honig LS, Doody R, van Dyck CH, Mulnard R, Barakos J, Gregg KM, Liu E, Lieberburg I, Schenk D, Black R, Gundman M: A phase 2 multiple ascending dose trial of bapineuzumab in mild to moderate Alzheimer disease. Neurol 2009, 73:2061-2070.

179. Kerchner GA, Boxer AL: Bapineuzumab. Expert Opin Biol Ther 2010, 10:1121-1130

180. Rinne JO, Brooks DJ, Rossor MN, Fox NC, Bullock R, Klunk WE, Mathis CA, Blennow K, Barakos J, Okello AA, Rodriguez Martinez de Liano S, Liu E, Koller M, Gregg KM, Schenk D, Black R, Grundman M: ${ }^{11} \mathrm{C}$-PiB PET assessment of change in fibrillar amyloid- $\beta$ load in patients with Alzheimer's disease treated with bapineuzumab: a phase 1, double-blind, placebo-controlled, ascending-dose study. Lancet Neurol 2010, 9:363-372.

181. Siemers ER, Friedrich S, Dean RA, Gonzales CR, Farlow MR, Paul SM, DeMattos RB: Safety and changes in plasma and cerebrospinal fluid amyloid $\beta$ after a single administration of an amyloid $\beta$ monoclonal antibody in subjects with Alzheimer disease. Clin Neuropharm 2010, 33:67-73.

182. Lemere CA, Masliah E: Can Alzheimer disease be prevented by amyloid- $\beta$ immunotherapy? Nat Rev Neurol 2010, 6:108-119.

183. Farlow M, Arnold SE, van Dyck CH, Aisen PS, Snider BJ, Porsteinsson AP, Friedrich S, Dean RA, Gonzales C, Sethuraman G, DeMattos RB, Mohs R, Paul SM, Siemers ER: Safety and biomarker effects of solanezumab in patients with Alzheimer's disease. Alzheimers Dement 2012, 8:261-271.

184. Lobello K, Ryan JM, Liu E, Rippon G, Black R: Targeting beta amyloid: a clinical review of immunotherapeutic approaches in Alzheimer's disease. Int J Alzheimers Dis 2012, 2012:628070.

185. Prins ND, Scheltens P: Treating Alzheimer's disease with monoclonal antibodies: current status and outlook for the future. Alzheimers Res Ther 2013, 5:56.

186. Doody RS, Thomas RG, Farlow M, Iwatsubo T, Vellas B, Joffe S, Kieburtz K, Raman R, Sun X, Aisen PS, Siemers E, Liu-Seifert H, Mohs R: Phase 3 trials of solanezumab for mild-to-moderate Alzheimer's disease. N Engl J Med 2014, 370:311-321.

187. Salloway S, Sperling R, Fox NC, Blennow K, Klunk W, Raskind M, Sabbagh M, Honig LS, Porsteinsson AP, Ferris S, Reichert M, Ketter N, Nejadnik B, Guenzler V, Miloslavsky M, Wang D, Lu Y, Lull J, Tudor IC, Liu E, Grundman M, Yuen E, Black R, Brashear RH: Two phase 3 trials of bapineuzumab in mild-to-moderate Alzheimer's disease. N Engl J Med 2014, 370:322-333.

188. Racke MM, Boone LI, Hepburn DL, Parsadainian M, Bryan MT, Ness DK, Piroozi KS, Jordan WH, Brown DD, Hoffman WP, Holtzman DM, Bales KR, Gitter BD, May PC, Paul SM, DeMattos RB: Exacerbation of cerebral amyloid angiopathy-associated microhemorrhage in amyloid precursor protein transgenic mice by immunotherapy is dependent on antibody recognition of deposited forms of amyloid $\beta$. J Neurosci 2005, 25:629-636.

189. Seubert $P$, Vigo-Pelfrey C, Esch F, Lee M, Dovey H, Davis D, Sinha S, Schlossmacher M, Whaley J, Swindlehurst C, McCormack R, Wolfert R, Selkoe D, Lieberbug I, Schenk D: Isolation and quantification of soluble Alzheimer's $\beta$-peptide from biological fluids. Nature 1992, 359:325-327.

190. DeMattos RB, Bales KR, Cummins DJ, Dodart J-C, Paul SM, Holtzman DM: Peripheral anti-A $\beta$ antibody alters CNS and plasma $A \beta$ clearance and decreases brain $A \beta$ burden in a mouse model of Alzheimer's disease. Proc Natl Acad Sci USA 2001, 98:8850-8855.

191. Yamada K, Yabuki C, Seubert P, Schenk D, Hori Y, Ohtsuki S, Terasaki T, Hashimoto T, Iwatsubo T: A $\beta$ immunotherapy: intracerebral sequestration of $A \beta$ by an anti-A $\beta$ monoclonal antibody 266 with high affinity to soluble $A \beta$. J Neurosci 2009, 29:11393-11398. 
192. Basi G, Jacobsen JS: Humanized abeta antibodies for use in improving cognition, United States Patent Application Publication Number US 2006/ 0198851 A1. 2006

193. Toolan D, Tugusheva K, Haugabook S, Feng M, McCampbell A, Hatcher N, Zhao W-Q, Gretzula C-A, Cash-Mason T, Lemaire P, Savage M, Shughrue P, Ray J, Renger J: Characterizing the selectivity of an antibody that targets a rare and unstable conformation of the $A \beta$ peptide in Alzheimer's disease. Unpublished internal research report, Merck \& Co; 2010, [http://www.acumenpharm.com/News/Toolan.pdf].

194. Bard F, Barbour R, Cannon C, Carretto R, Fox M, Games D, Guido T, Hoenow K, Hu K, Johnson-Wood K, Khan K, Kholodenko D, Lee C, Lee M, Motter R, Nguyen M, Reed A, Schenk D, Tang P, Vasquez N, Seubert P, Yednock T: Epitope and isotype specificities of antibodies to $\beta$-amyloid peptide for protection against Alzheimer's disease-like neuropathology. Proc Natl Acad Sci USA 2003, 100:2023-2028.

195. Schenk D, Barbour R, Dunn W, Gordon G, Grajeda H, Guido T, Hu K, Huang J, Johnson-Wood K, Khan K, Kholodenko D, Lee M, Liao Z, Lieberburg I, Motter R, Mutter L, Soriano F, Shopp G, Vasquez N, Vandevert C, Walker S, Wogulis M, Yednock T, Games D, Seubert P: Immunization with amyloid- $\beta$ attenuates Alzheimer-disease-like pathology in the PDAPP mouse. Nature 1999 400:173-177.

196. Bard F, Cannon C, Barbour R, Burke R-L, Games D, Grajeda H, Guido T, Hu K, Huang J, Kohnson-Wood K, Khan K, Kholodenko D, Lee M, Lieberburg I, Motter R, Nguyen M, Soriano F, Vasquez N, Weiss K, Welch B, Seubert P, Schenk D, Yednock T: Peripherally administered antibodies against amyloid $\beta$-peptide enter the central nervous system and reduce pathology in a mouse model of Alzheimer disease. Nat Med 2000, 6:916-919.

197. Basi G, Saldanha J, Yednock T: Humanized antibodies that recognize beta amyloid peptide, World Intellectual Property Organization International Publication Number WO 02/46237 A2. 2002.

198. Johnson-Wood K, Lee M, Motter R, Hu K, Gordon G, Barbour R, Khan K, Gordon M, Tan H, Games D, Lieberburg I, Schenk D, Seubert P, McConlogue $L$ : Amyloid precursor protein processing and $A \beta_{42}$ deposition in a transgenic mouse model of Alzheimer disease. Proc Natl Acad Sci USA 1997, 94:1550-1555.

199. Buttini M, Masliah E, Barbour R, Grajeda H, Motter R, Kohnson-Wood K, Kham K, Seubert P, Freedman S, Schenk D, Games D: $\beta$-Amyloid immunotherapy prevents synaptic degeneration in a mouse model of Alzheimer's disease. J Neurosci 2005, 25:9096-9101.

200. Schroeter S, Khan K, Barbour R, Doan M, Chen M, Guido T, Gill D, Basi G, Schenk $D$, Seubert $P$, Games D: Immunotherapy reduces vascular amyloid- $\beta$ in PDAPP mice. J Neurosci 2008, 28:6787-6793.

201. Bard F, Fox M, Friedrich S, Seubert P, Schenk D, Kinney GG, Yednock T: Sustained levels of antibodies against $A \beta$ in amyloid-rich regions of the CNS following intravenous dosing in human APP transgenic mice. Exp Neurology 2012, 238:38-43

202. Blennow K, Zetterberg H, Rinne JO, Salloway S, Wei J, Black R, Grundman M, Liu E: Effect of immunotherapy with bapineuzumab on cerebrospinal fluid biomarker levels in patients with mild to moderate Alzheimer disease. Arch Nuerol 2012, 69:1002-1010.

203. Pfeifer A, Pihlgren M, Muhs A, Watts R: Humanized antibodies to amyloid beta, World Intellectual Property Organization International Publication Number WO 2008/156622 A1. 2008

204. Adolfsson O, Pihlgren M, Toni N, Varisco Y, Buccarello AL, Antoniello K, Lohmann S, Piorkowska K, Gafner V, Atwal JK, Maloney J, Chen M, Gogineni A, Weimer RM, Mortensen DL, Friesenhahn M, Ho C, Paul R, Pfeifer A, Muhs A, Watts RJ: An effector-reduced anti- $\beta$-amyloid $(A \beta)$ antibody with unique $A \beta$ binding properties promotes neuroprotection and glial engulfment of $A \beta$. J Neurosci 2012, 32:9677-9689.

205. Rosenthal A, Ponns J, Ho W-H, Grimm JM: Antibodies directed against amyloid-beta peptide and methods using same, World Intellectual Property Organization International Publication Number WO 2006/036291 A2. 2006.

206. Carty NC, Wilcock DM, Rosenthal A, Grimm J, Pons J, Ronan V, Gottschall PE, Gordon MN, Morgan D: Intracranial administration of deglycosyoated C-terminal-specific anti-A $\beta$ antibody efficiently clears amyloid plaques without activating microglia in amyloid-depositing transgenic mice. J Neuroinflammation 2006, 3:11.

207. La Porte SL, Bollini SS, Lanz TA, Abdiche YN, Rusnak AS, Ho W-H, Kobayashi D, Harrabi O, Pappas D, Mina EW, Milici AJ, Kawbe TT, Bales K, Lin JC, Pons J: Structural basis of $C$-terminal $\beta$-amyloid peptide binding by the antibody ponezumab for treatment of Alzheimer's disease. J Mol Biol 2012, 421:525-536.

208. Nitsch R, Hock C, Esslinger C, Knobloch M, Tissot K: Method of providing disease-specific binding molecules and targets, World Intellectual Property Organization International Publication Number WO 2008/081008 A1. 2008.

209. Dunstan R, Bussiere T, Rhodes K, Engber T, Maier M, Weinreb P, Grimm J, Nitsch R, Arustu M, Qian F, Li M: Molecular characterization and preclinical efficacy. Alzheimers Dement 2011, 7:S457.

210. Englund $H$, Sehlin D, Johansson A-S, Nilsson LNG, Gellerfors P, Paulie $S$, Lannfelt L, Pettersson FE: Sensitive ELISA detection of amyloid- $\beta$ protofibrils in biological samples. J Neurochem 2007, 103:334-345.

211. Nilsberth C, Westlind-Danielsson A, Eckman CB, Condron MM, Axelman K, Forsell C, Stenh C, Luthman J, Teplow DB, Younkin SG, Näslund J, Lannfelt L: The 'Artic' APP mutation (E693G) causes Alzheimer's disease by enhanced $A \beta$ protofibril formation. Nat Neurosci 2001, 4:887-893.

212. Kayed R, Head E, Thompson JL, McIntire TM, Milton SC, Cotman CW, Glabe CG: Common structure of soluble amyloid oligomers implies common mechanism of pathogenesis. Science 2003, 300:486-489.

213. Lord A, Gumucio A, Englund H, Sehlin D, Sundquist VS, Söderberg L, Möller C Gellerfors P, Lannfelt L, Pettersson FE, Nilsson LN: An amyloid- $\beta$ protofibril-selective antibody prevents amyloid formation in a mouse model of Alzheimer's disease. Neurobiol Dis 2009, 36:425-434.

214. Gellerfors P, Lannfelt L, Sehlin D, Pettersson FE, Englund H: Protofibril selective antibodies and the use thereof, United States Patent Application Publication Number US 2009/0258009 A1. ; 2009.

215. Bohrmann B, Baumann K, Benz J, Gerber F, Huber W, Knoflach F, Messer J, Oroszlan K, Rauchenberger R, Richter WF, Rothe C, Urban M, Bardroff M, Winter M, Nordstedt C, Loetscher H: Gantenerumab: a novel human anti-A $\beta$ antibody demonstrates sustained cerebral amyloid- $\beta$ binding and elicits cell-mediated removal of human amyloid- $\beta$. J Alzheimers Dis 2012, 28:49-69.

216. Ostrowitzki S, Deptula D, Thurfjell L, Barkhof F, Bohrmann B, Brooks DJ, Klunk WE, Ashford E, Yoo K, Xu Z-X, Loetscher H, Santarelli L: Mechanism of amyloid removal in patients with Alzheimer disease treated with gantenerumab. Arch Neurol 2012, 69:198-207.

217. Schupf N, Tang MX, Fukuyama H, Manly J, Andrews H, Mehta P, Ravetch J, Mayeux R: Peripheral $A \beta$ subspecies as risk biomarkers of Alzheimer's disease. Proc Natl Acad Sci USA 2008, 105:14052-14057.

218. Ravetch J, Fukuyama H: Antibodies specific for the protofibril form of beta-amyloid protein, World Intellectual Property Organization, International Publication Number WO 2009/065054 A3. 2009.

219. Pradier L, Cohen C, Blanchard V, Debeir T, Barneoud P, Canton T, Menager J, Bohme A, Rooney T, Guillet M-C, Cameron B, Shi Y, Naimi S, Ravetch J, Claudel S, Alam J: SAR228810: an antiprotofibrillar beta-amyloid antibody designed to reduce risk of amyloid-related imaging abnormalities (ARIA). Alzheimers Dement 2013, 9:P808-P809.

220. Baurin N, Blanche F, Cameron B, Duchesne M, Mikol V, Naimi S, Pradier L, Shi Y: Humanized antibodies specific to the protofibrillar form of the betaamyloid peptide, United States Patent Application Publication No. US 2012/ 0177639. 2012

221. Dodel R, Balakrishnan K, Keyvani K, Deuster O, Neff F, Andrei-Selmer L-C, Röskam S, Stüer C, Al-Abed Y, Noelker C, Balzer-Geldsetzer M, Oertel W, Du Y, Bacher M: Naturally occurring autoantibodies against $\beta$-amyloid: investigating their role in transgenic animal and in vitro models of Alzheimer's disease. J Neurosci 2011, 31:5847-5854.

222. Moir RD, Tseitlin KA, Soscia S, Hyman BT, Irizarry MC, Tanzi RE: Autoantibodies to redox-modified oligomeric $A \beta$ are attenuated in the plasma of Alzheimer's disease patients. J Biol Chem 2005, 280:17458-17463.

223. Szabo P, Relkin N, Weksler ME: Natural human antibodies to amyloid beta peptide. Autoimmunity Rev 2008, 7:415-420.

224. Lambert MP, Velasco PT, Chang L, Viola KL, Fernandez S, Lacor PN, Khuon D, Gong Y, Bigio EH, Shaw P, De Felice FG, Krafft GA, Klein WL: Monoclonal antibodies that target pathological assemblies of A 3 . J Neurochem 2007, 100:23-35.

\subsection{6/alzrt272}

Cite this article as: Goure et al:: Targeting the proper amyloid-beta neuronal toxins: a path forward for Alzheimer's disease immunotherapeutics. Alzheimer's Research \& Therapy 2014, 6:42 